
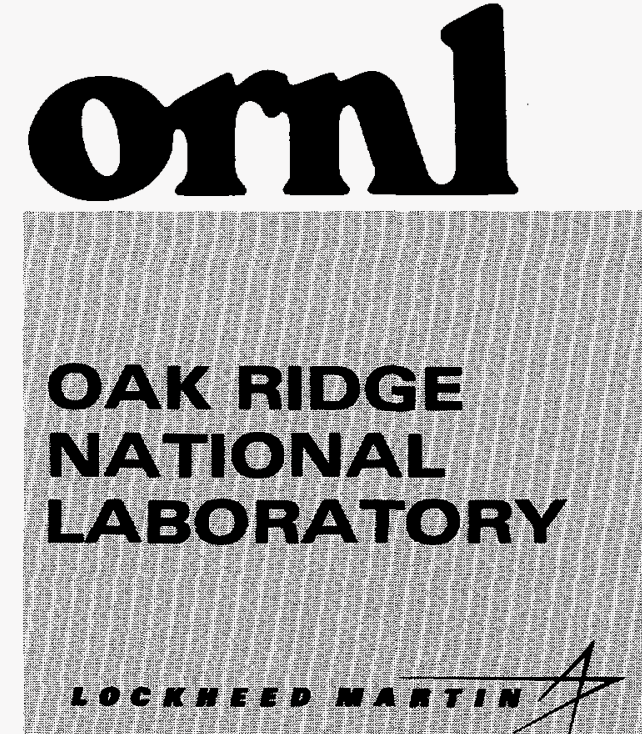

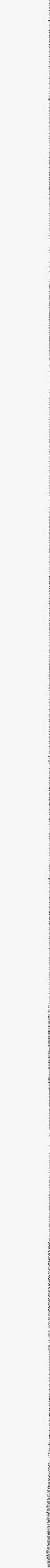

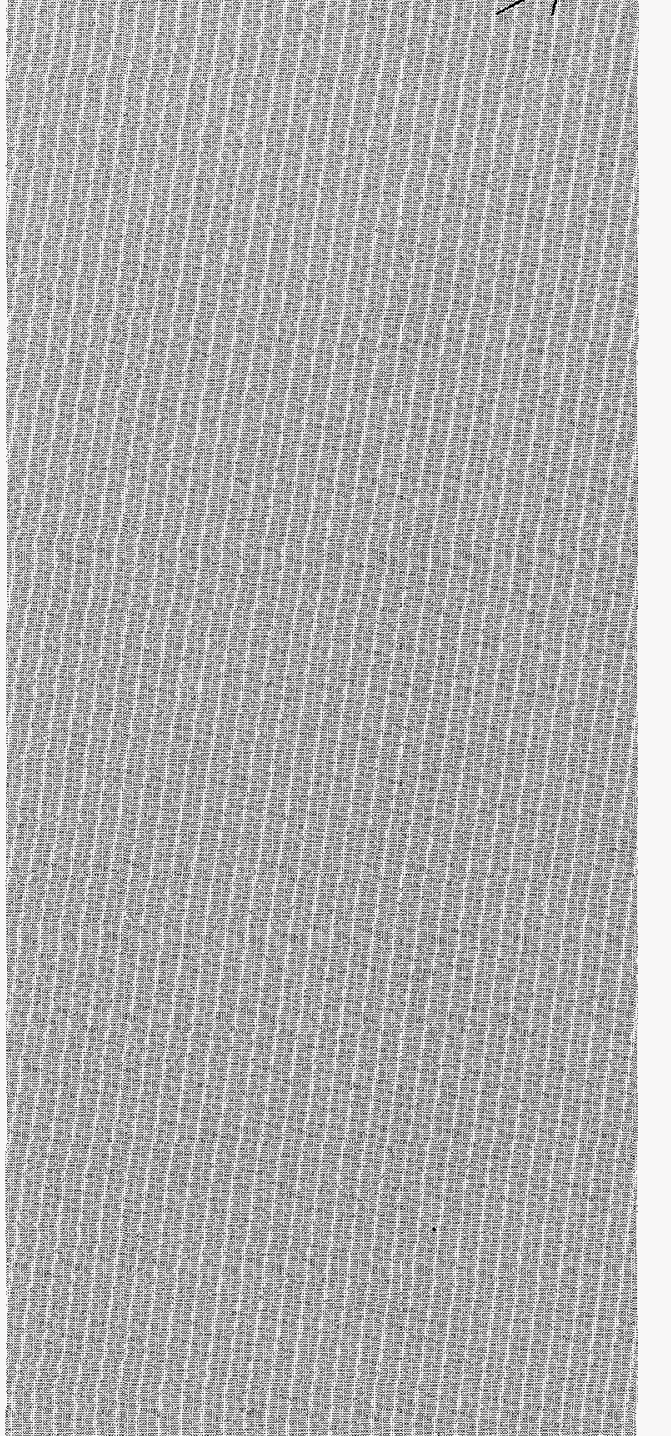

WAYleza MD OPERATED BY LOCKHEEO WAHMY ENERCY RESEARCH CORPORANON

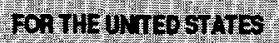
DEPLTIUET OF ENERET
Wres

oct 169906

OSTI

ENVIRONMENTAL SCIENCES DIVISION

\section{BIOAVAILABILITY STUDY FOR THE PADUCAH GASEOUS DIFFUSION PLANT}

T. L. Phipps and L. A. Kszos

Environmental Sciences Division

Publication No. 4568

August 1996
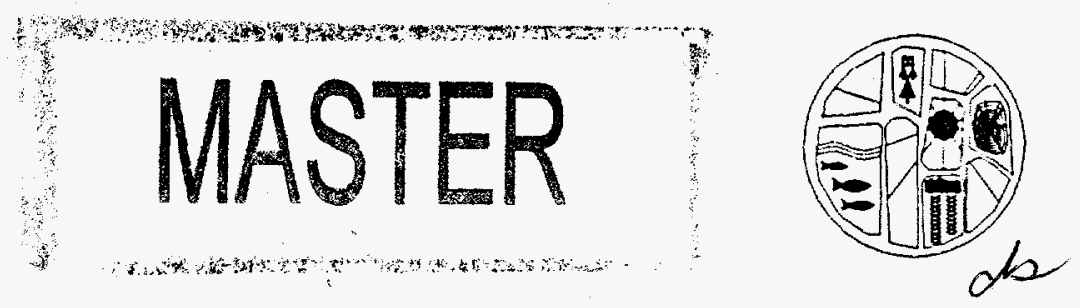

DISTRIBUTION OF THIS DOCUMENT IS UNLMTTED 
This report has been reproduced directly from the best available copy.

Available to DOE and DOE contractors from the Office of Scientific and Technical Information, P. O. Box 62, Oak Ridge, TN 37831; prices available from (423) 576-8401, FTS 626-8401.

Available to the public from the National Technical Information Service, U.S. Department of Commerce, 5285 Port Royal Road, Springfield, VA 22161.

This report was prepared as an account of work sponsored by an agency of the United States Government. Neither the United States Government nor any agency thereof, nor any of their employees, makes any warranty, express or implied, or assumes any legal liability or responsibility for the accuracy, completeness, or usefulness of any information, apparatus, product, or process disclosed, or represents that its use would not infringe privately owned rights. Reference herein to any specific commercial product, process, or service by trade name, trademark, manufacturer, or otherwise, does not necessarily constitute or imply its endorsement, recommendation, or favoring by the United States Government or any agency thereof. The views and opinions of authors expressed herein do not necessarily state or reflect those of the United States Government of any agency thereof. 
CONTENTS

Page

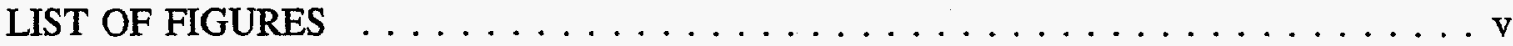

LIST OF TABLES $\ldots \ldots \ldots \ldots \ldots \ldots \ldots \ldots \ldots \ldots \ldots \ldots \ldots \ldots \ldots$

ACRONYMS $\ldots \ldots \ldots \ldots \ldots \ldots \ldots \ldots \ldots \ldots \ldots \ldots \ldots \ldots \ldots \ldots$ ix

EXECUTTVE SUMMARY $\ldots \ldots \ldots \ldots \ldots \ldots \ldots \ldots \ldots \ldots \ldots \ldots \ldots$

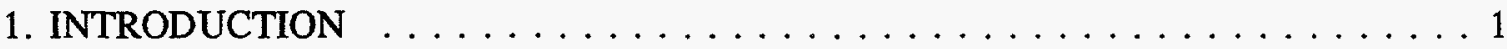

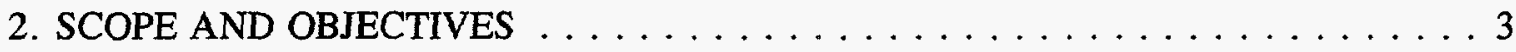

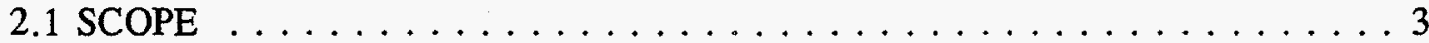

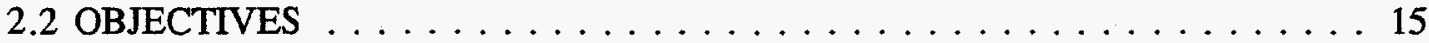

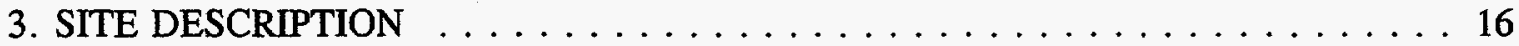

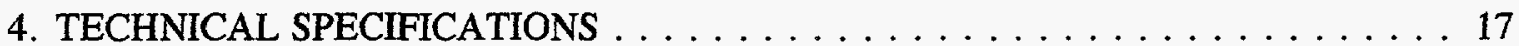

4.1 MONITORING SCHEDULE $\ldots \ldots \ldots \ldots \ldots \ldots \ldots \ldots \ldots \ldots \ldots$

4.2 MONITORING DURATION $\ldots \ldots \ldots \ldots \ldots \ldots \ldots \ldots \ldots \ldots \ldots$

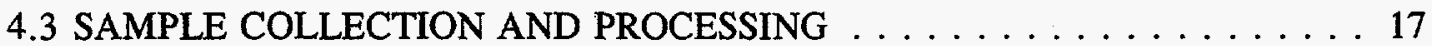

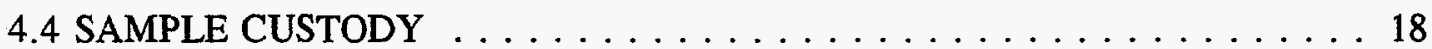

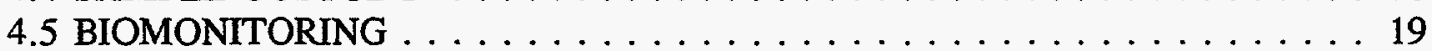

4.6 LABORATORY ANALYSIS OF TOTAL RECOVERABLE AND

DISSOLVED METALS . . . . . . . . . . . . . . . . . . . . 19

4.7 ADDITIONAL PHYSICAL/CHEMICAL ANALYSES . . . . . . . . . . 19

4.8 MEASUREMENT ENDPOINTS $\ldots \ldots \ldots \ldots \ldots \ldots \ldots$

5. QUALITY ASSURANCE/QUALITY CONTROL $\ldots \ldots \ldots \ldots \ldots \ldots \ldots$

5.1 QUALITY CONTROL SAMPLE CHECKS . . . . . . . . . . . . 21

5.1 .1 Field Data Quality . . . . . . . . . . . . . . . . . 22

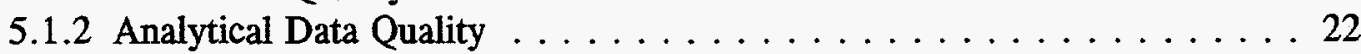

5.1 .3 Toxicity Data Quality . . . . . . . . . . . . . . . 24

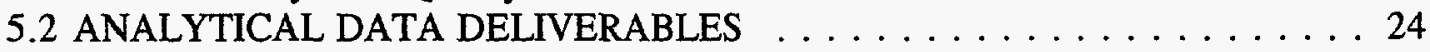

5.3 INCORPORATION OF EPA "CLEAN" TECHNIQUES . . . . . . . . . . . 24

6. TOXICITY IDENTIFICATION EVALUATION $\ldots \ldots \ldots \ldots \ldots \ldots \ldots$

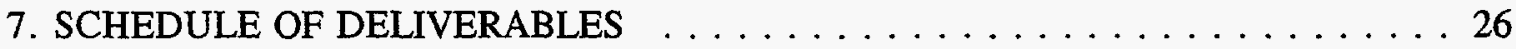

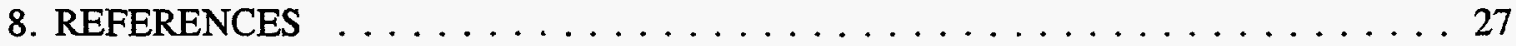


CONTENTS (continued)

Page

Appendix A: KENTUCKY DEPARTMENT OF ENVIRONMENTAL

PROTECTION KENTUCKY DIVISION OF WATER

PROCEDURES TO FACILITATE ALTERNATIVE

METAL LIMITS

Appendix B: AGREED ORDER OF DISMISSAL $\ldots \ldots \ldots \ldots \ldots \ldots$ 


\section{DISCLAMMER}

Portions of this document may be illegible in electronic image products. Images are produced from the best available original document. 


\section{LIST OF FIGURES}

Figure

Page

2.1. Location of KPDES-permitted outfalls for the Paducah Gaseous Diffusion Plant . . 4 


\section{LIST OF TABLES}

Table

Page

2.1 Results of effluent biomonitoring tests for continuous outfalls $001,006,008$,

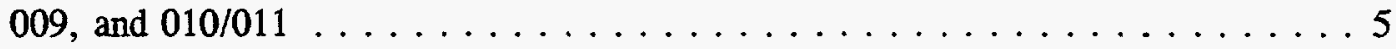

2.2 Results of effluent biomonitoring tests for intermittent outfalls $013,015,016$,

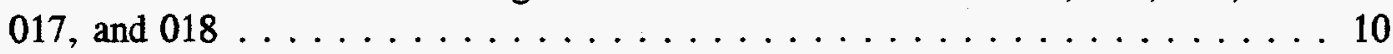

2.3 Number of permit exceedances from the KPDES permit (from November 1, 1992, through February 29,1996$)$ for PGDP outfalls . . . . . . . . . . . 15

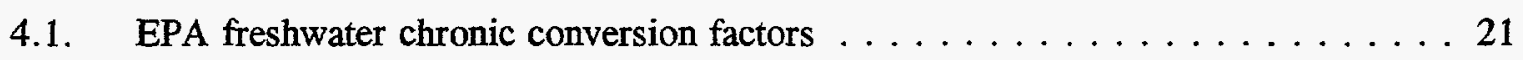

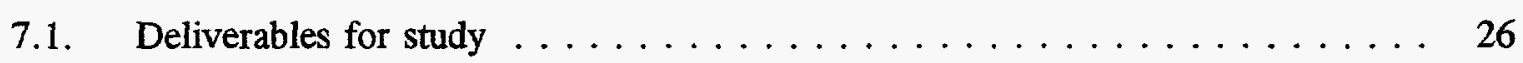




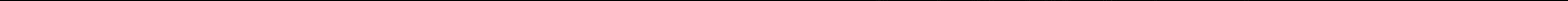




\section{ACRONYMS}

$\begin{array}{ll}\text { COC } & \text { chain-of-custody } \\ \text { DOE } & \text { U. S. Department of Energy } \\ \text { EPA } & \text { U. S. Environmental Protection Agency } \\ \text { IC } & \text { inhibition concentration } \\ \text { KDOW } & \text { Kentucky Division of Water } \\ \text { KPDES } & \text { Kentucky Pollutant Discharge Elimination System } \\ \text { LMES } & \text { Lockheed Martin Energy Systems, Inc. } \\ \text { LMUS } & \text { Lockheed Martin Utility Systems, Inc. } \\ \text { MDL } & \text { method detection limit } \\ \text { NPDES } & \text { National Pollutant Discharge Elimination System } \\ \text { NTR } & \text { National Toxics Rule } \\ \text { PGDP } & \text { Paducah Gaseous Diffusion Plant } \\ \text { SAP } & \text { Sampling and Analysis Plan } \\ \text { TR } & \text { total recoverable } \\ \text { TSO } & \text { Technical Subcontracting Office } \\ \text { TUc } & \text { chronic toxicity unit } \\ \text { USEC } & \text { United States Enrichment Corporation } \\ \text { WER } & \text { water-effect ratio } \\ \text { WQC } & \text { water quality criteria }\end{array}$




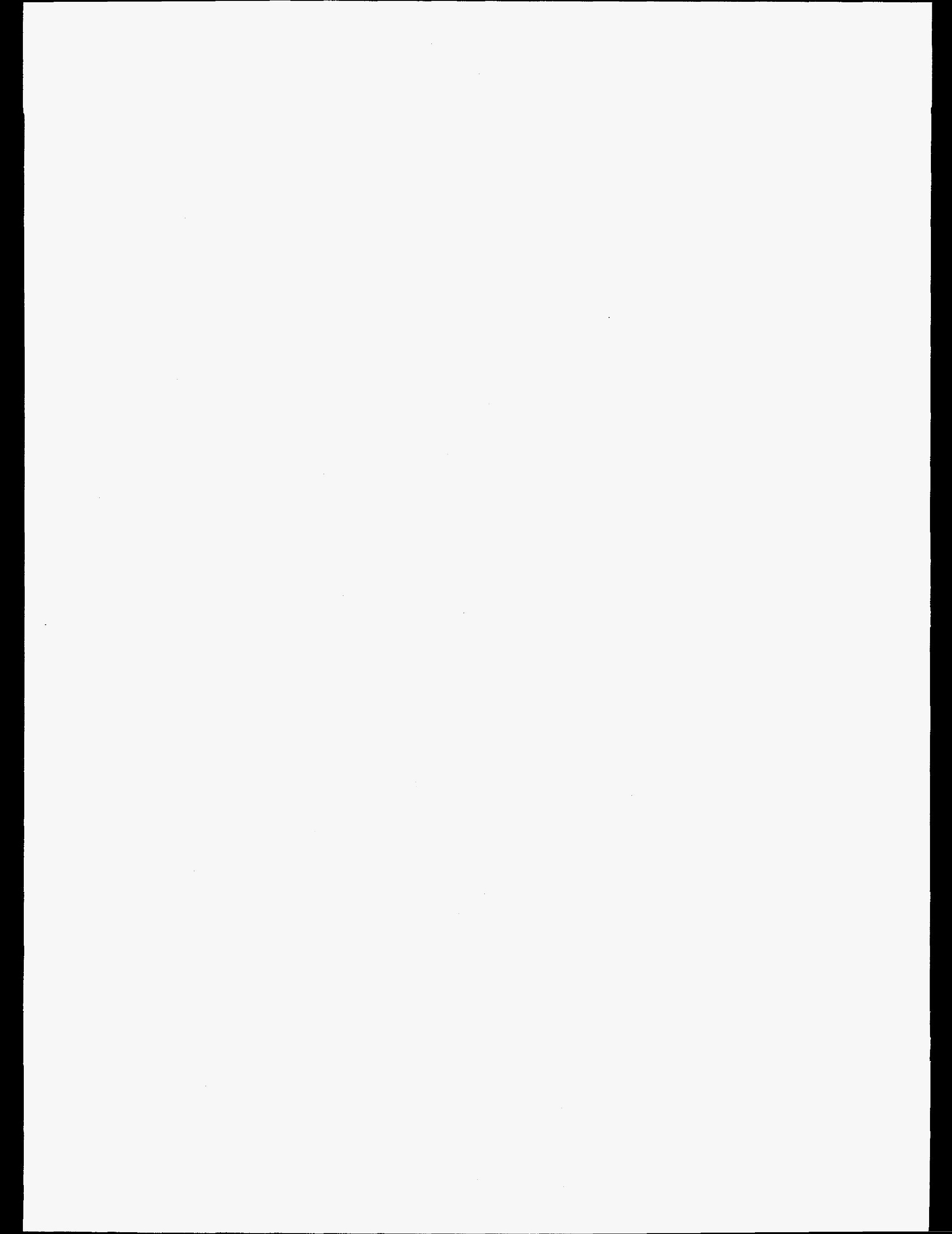




\section{EXECUTIVE SUMMARY}

The overall purpose of this plan is to assess the bioavailability of metals in the continuous and intermittent outfalls. The results may be used to determine alternative metal limits that more appropriately measure the portion of metal present necessary for toxicity to aquatic life. These limits must remain protective of in-stream aquatic life; thus, the highest concentration of metal in the water will be determined concurrently with an assessment of acute or chronic toxicity in laboratory tests.

The Clean Water Act is administered for the Paducah Gaseous Diffusion Plant (PGDP) by the Kentucky Division of Water (KDOW) through the Kentucky Pollutant Discharge Elimination System (KDPES) Wastewater Discharge Permitting Program. The PGDP operates under KPDES Permit No. KY0004049 issued September 29, 1992. The permit became effective November 1, 1992, and is enforced by the KDOW. Metals criteria applied to the KPDES permit are total recoverable metals measured in unfiltered water samples.

On April 5, 1996, the Commonwealth of Kentucky Natural Resources and Environmental Protection Cabinet issued an Agreed Order that required the development of a plan to conduct studies that would identify alternative metal limits for Department of Energy (DOE) and United States Enrichment Corporation (USEC) outfalls 001, 002, 003, 008, 009, 010, 011, $012,013,015,016,017$, and 018 . Except during heavy rainfall events, outfalls 002,010 , 011, and 012 will be composited in the C-617 lagoon and discharged from outfall 010. Alternative metal limits may be developed for cadmium, chromium, copper, lead, nickel, and zinc. As stipulated in the Agreed Order, DOE/USEC must demonstrate to the satisfaction of the Cabinet that a more appropriate analytical technique or criteria is available that provides a better measurement of levels of metals present that would be toxic to aquatic life.

In May 1996, the KDOW issued revised Procedures to Facilitate Alternative Metals Limits. The revised KDOW procedure provides an alternative method for deriving site-specific metals limits; combining biomonitoring with chemical-specific analyses. The procedure provides an alternative method of measuring compliance to total recoverable metal limits. KDOW developed these procedures to address derivation of alternative metal limits for discharges into zero flow streams. Alternative permit limits are determined by multiplying the total recoverable metal concentration by the dissolved metal:total recoverable (TR) metal ratio. The result is then multiplied by the reciprocal of the U.S. Environmental Protection Agency's (EPA's) freshwater criteria conversion factor for each metal of concern.

Metal concentration of effluent $=($ TR metal $\times$ dissolved:TR ratio $) \times 1 /$ EPA Eq. 1 criteria conversion factor

Using the method developed by the KDOW, biomonitoring results and chemical data will be used to recommend alternative metal limits for the outfalls of concern. The data will be used to meet the objectives of the study:

- evaluate the toxicity of continuous outfalls $(001,008,009$, and 010$)$ and intermittent outfalls $(003,013,015,016,017$, and 018) at PGDP,

- determine the mean ratio of dissolved to TR metal for $\mathrm{Cd}, \mathrm{Cr}, \mathrm{Cu}, \mathrm{Pb}, \mathrm{Ni}$, and $\mathrm{Zn}$ in the continuous and intermittent outfalls, 
- determine whether the concentration of TR metal discharged causes toxicity to fathead minnows and/or Ceriodaphnia, and

- determine alternative metal limits for each metal of concern $(\mathrm{Cd}, \mathrm{Cr}, \mathrm{Cu}, \mathrm{Pb}, \mathrm{Ni}$, and $\mathrm{Zn})$. 


\section{INTRODUCTION}

The U.S. Environmental Protection Agency (EPA) National Guidelines (Stephan et al. 1985) describe procedures for deriving national water quality criteria (WQC) for the protection of aquatic life. Incorporating national or state WQC into National Pollutant Discharge Elimination System (NPDES) permits assumes that if the aqueous concentration of a material in a body of water is lower than the criterion, the aquatic life in that body of water is unlikely to be affected adversely. Using standardized criteria is more cost-effective than developing site-specific criteria, so standardized criteria have been used since the $1980 \mathrm{~s}$. To determine compliance with standardized criteria for metals, the EPA has recommended using measurements of total recoverable (TR) metals. Beginning in 1984, the WQC documents recommended the use of an acid-soluble method for determining concentrations of metals of concern. Either of these methods-TR or acid-soluble-may result in the overestimation of toxicity, because not all of the measured metals are bioavailable.

A major issue in the scientific and regulatory communities is whether, and how, to use dissolved metal concentrations or TR metal concentrations in setting state water quality standards. Under the National Toxics Rule (NTR), the EPA used TR metals to express metals criteria because this approach is more conservative and provides a greater level of protection than dissolved metal measurement. The NTR metals criteria were challenged, and in May 1995, the EPA issued a Stay of Federal Water Quality Criteria for Metals (40 CFR Part 131). It is now the policy of the EPA's Office of Water that dissolved metal, rather than

TR metal, better approximates the fraction of waterborne metals that are biologically available to aquatic organisms. Subsequently, the use of dissolved metal is the recommended approach to setting and measuring compliance with water quality standards. One reason for this change is that the bioavailable or dissolved fraction of metal present will more likely be toxic to aquatic organisms.

The bioavailability of most toxic metals is strongly affected by factors such as the types and concentrations of dissolved and particulate organic matter in the water, $\mathrm{pH}$, and metalbinding dissolved constituents, such as sulfide. These factors are not routinely incorporated into present WQC. In May 1992, the EPA issued new guidance for interpreting and implementing WQC for metals in waters of the United States to address issues of bioavailability (EPA 1992). This new guidance document provides new approaches for developing site-specific criteria. These approaches account for the fact that naturally occurring materials in ambient waters can reduce the bioavailability and, thus, lower the toxicity of various metals. In one alternative, measurements of dissolved metals in ambient waters are compared to criteria appropriate for dissolved metals. In another approach, the toxicity of a metal in ambient water is compared directly to the toxicity of that metal in laboratory water. The national criterion for that metal is then adjusted by the ratio of toxicity in ambient site water to the toxicity in laboratory water. This latter method is referred to as the water-effect ratio (WER).

The EPA has issued guidance for three methodologies that can be used for the development of site-specific criteria: indicator species procedure (WER), recalculation procedure, and resident species procedure (EPA 1994). Use of the WER takes into account differences between toxicity of a metal in laboratory dilution water and its toxicity in site water. Determining the WER is an approach that can be used by dischargers who want higher permit limits. An alternative approach for determining site-specific metals criteria 
involves application of the Recalculation Procedure. This method takes into account differences in aquatic species that occur at the site and those species used in the derivation of the national criterion. However, the Recalculation Procedure cannot be used to derive sitespecific metals criteria in jurisdictions subject to the NTR.

The EPA method provides guidance for deriving WERs in zero flow streams. The sitespecific criterion is derived by dividing the endpoint [e.g., inhibition concentration (IC) ${ }_{25}$ ] obtained in the site water by the endpoint obtained in the laboratory dilution water. Either TR metal or dissolved metal WERs can be calculated. Also, WERs are determined individually for each metal at each site; that is, WERs calculated for one metal cannot be extrapolated to another metal, from one effluent to another, or from one site water to another. Several factors need to be considered before determining site-specific criteria using the WER approach:

- Some WERs will be substantially greater than 1.0 , some will be approximately 1.0 , and some will be less than 1.0 .

- The WER approach requires substantial resources.

- More cost-effective methods than determining a WER are available to the discharger.

Several site-specific factors can significantly affect the toxicity of metals and must be considered in the management of metals in an aquatic environment. These factors include toxicity specific to effluent chemistry; toxicity specific to ambient water chemistry; different patterns of toxicity (e.g., increased mortality, reduced fecundity or growth, reduced mobility) for different metals; fate and transport mechanisms; resource limitations for monitoring, analysis, and research; concerns regarding the quality of data currently on record due to possible sample and analytical contamination; and lack of standardized protocols for clean metals analysis.

In May 1996, the Kentucky Division of Water (KDOW) issued Procedures to Facilitate Alternative Metal Limits (Appendix A) that could be used in lieu of the WER. This procedure was put forth to allow dischargers to demonstrate "that a form of metal other than TR is the cause of toxicity." In general, the procedure requires demonstration, through chemicalspecific analyses and biomonitoring, that an effluent is not toxic as a result of the presence of the metal in question. Language in Kentucky's regulations was recently changed to allow the use of methods other than the TR method to measure attainment of aquatic-life criteria for metals. Based on the Agreed Order signed April 5, 1996, the Department of Energy (DOE) and United States Enrichment Corporation (USEC) may attempt to develop alternative metal limits for $\mathrm{Cd}, \mathrm{Cu}, \mathrm{Pb}, \mathrm{Ni}, \mathrm{Zn}$, trivalent chromium $[\mathrm{Cr}(\mathrm{III})]$, and hexavalent chromium [Cr(VI)] (Appendix B). A successful demonstration by Paducah Gaseous Diffusion Plant (PGDP) could result in a modification of the permit to incorporate alternative metals limits.

Metals in the environment are usually present in complexed or particulate forms, and only a small fraction of total metal concentration is bioavailable. The changes in physical and chemical forms of certain metals will directly relate to their toxicity toward aquatic organisms. Using the method developed by the KDOW, information obtained from biomonitoring tests as well as analyses of the effluent for TR and dissolved metals will be used to determine whether the concentration of TR metal discharged is toxic to fathead minnows (Pimephales promelas) and Ceriodaphnia dubia. 


\section{SCOPE AND OBJECTIVES}

The overall purpose of this plan is to assess the bioavailability of metals in the continuous and intermittent outfalls. The results may be used to determine alternative metal limits that more appropriately measure the portion of metal present necessary for toxicity to aquatic life. These limits must remain protective of in-stream aquatic life; thus, the highest concentration of metal in the water will be determined concurrently with an assessment of acute or chronic toxicity in laboratory tests.

\subsection{SCOPE}

The KDOW administers the Clean Water Act for PGDP through the KPDES Wastewater Discharge Permitting Program. PGDP operates under KPDES Permit No. KY0004049, which was issued September 29, 1992, and became effective November 1, 1992. Biomonitoring tests using aquatic organisms are conducted quarterly for outfalls 001, 006, 008, 009, 010, 013, 015, 016, 017, and 018. (Outfalls 002, 010, 011, and 012 are composted in C-617 and discharged via Outfall 010). Outfalls 001, 006, 008, and 009 discharge continuously to Big Bayou Creek (Fig. 2.1). Outfall 010 discharges continuously to Little Bayou Creek. Outfalls 015, 016, and 017 discharge intermittently to Big Bayou Creek and outfall 018 discharges intermittently to Little Bayou Creek (Fig. 2.1). During heavy rainfall, outfalls 002, 011, and 012 may discharge to Little Bayou Creek.

The Environmental Sciences Division (ESD) Aquatic Toxicology Laboratory at Oak Ridge National Laboratory (ORNL) began evaluating the toxicity of continuous and intermittent outfalls at PGDP in October 1991. Quarterly biomonitoring tests are conducted using fathead minnows and/or $C$. dubia. The $25 \%$ inhibition concentration (IC25: the concentration that causes a $25 \%$ reduction in fathead minnow growth or Ceriodaphnia reproduction) was determined for each outfall tested. The compliance endpoint in the permit is expressed as chronic toxicity units (TUc $=100 / \mathrm{IC} 25$ ). The higher the TUc, the more toxic the effluent.

Since October 1991, the monitored outfalls have exhibited periodic toxicity. Table 2.1 summarizes the TUcs for all biomonitoring tests of continuous outfalls conducted October 1991-May 1996. Table 2.2 is a summary of the TUcs for biomonitoring tests of the intermittent outfalls conducted December 1991-April 1996.

The KPDES effluent permit limits for various metals in these effluents are occasionally exceeded. Table 2.3 summarizes, by outfall, the number of permit exceedances for each metal of concern.

In accordance with the Agreed Order, a study to develop alternative metal limits will be conducted for DOE and USEC outfalls 001, 002, 003, 008, 009, 010, 011, 012, 013, 015, 016, 017, and 018. Except during heavy rainfall events, outfalls $002,010,011$, and 012 are composited in the C-617 lagoon and discharged from Outfall 010.

Although not part of this plan, it is important to recognize that the Biological Monitoring Program will be ongoing during this study. The data from this program will provide additional information concerning the ecological health of the receiving streams, Big Bayou and Little Bayou creeks. 


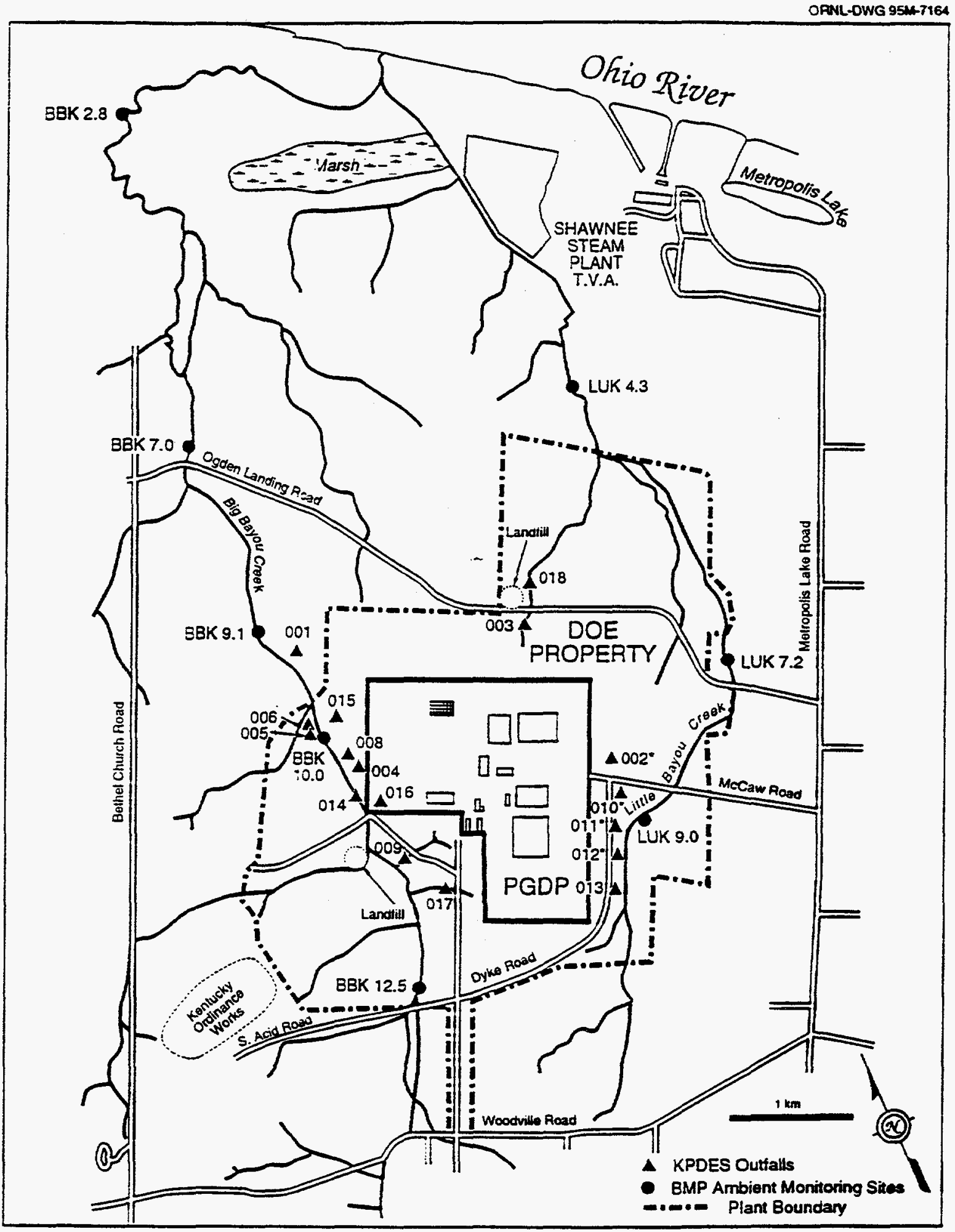

"Combined at C617 pond and discharged through $011 / 010$

Fig. 2.1. Location of KPDES permitted outfalls for the Paducah Gaseous Diffusion Plant. 
Table 2.1. Results of effluent biomonitoring tests for continuous outfalls 001, 006, 008, 009, and $010 / 011$

\begin{tabular}{|c|c|c|c|}
\hline \multirow{2}{*}{ Outfall } & \multirow{2}{*}{ Test date } & \multicolumn{2}{|c|}{ Chronic toxicity units (TUc) ${ }^{a}$} \\
\hline & & Fathead minnow & Ceriodaphnia \\
\hline \multirow[t]{21}{*}{001} & October 1991 & $\mathrm{ND}^{b}$ & $<1$ \\
\hline & February 1992 & $<1$ & $<1$ \\
\hline & May 1992 & $\mathrm{ND}^{b}$ & 4.5 \\
\hline & August 1992 & $<1$ & $<1$ \\
\hline & October 1992 & $<1$ & $<1$ \\
\hline & February 1993 & $<1$ & $<1$ \\
\hline & May 1993 & $<1$ & $<1$ \\
\hline & August 1993 & $<1$ & $<1$ \\
\hline & October 1993 & $<1$ & 1.09 \\
\hline & March 1994 & $<1$ & $<1$ \\
\hline & May 1994 & $<1$ & $<1$ \\
\hline & August 1994 & $<1$ & $<1$ \\
\hline & October 1994 & $<1$ & $\mathrm{I}^{d}$ \\
\hline & November 1994 & $\mathrm{NT}^{c}$ & $<1$ \\
\hline & March 1995 & $<1$ & $<1$ \\
\hline & May 1995 & $<1$ & $<1$ \\
\hline & August 1995 & $<1$ & $<1$ \\
\hline & October 1995 & $<1$ & 9.18 \\
\hline & November 1995 & $\mathrm{NT}^{c}$ & 1.59 \\
\hline & March 1996 & $<1$ & $<1$ \\
\hline & May 1996 & $<1$ & $<1$ \\
\hline
\end{tabular}


Table 2.1 (continued)

\begin{tabular}{|c|c|c|c|}
\hline \multirow{2}{*}{ Outfall } & \multirow{2}{*}{ Test date } & \multicolumn{2}{|c|}{ Chronic toxicity units (TUc) ${ }^{a}$} \\
\hline & & Fathead minnow & Ceriodaphnia \\
\hline \multirow[t]{23}{*}{006} & October 1991 & $\mathrm{ND}^{b}$ & $<1$ \\
\hline & February 1992 & 1.39 & 1.56 \\
\hline & May 1992 & $\mathrm{ND}^{b}$ & $<1$ \\
\hline & August 1992 & $<1$ & $<1$ \\
\hline & October 1992 & $<1$ & $<1$ \\
\hline & February 1993 & $<1$ & $<1$ \\
\hline & May 1993 & $<1$ & $\mathrm{I}^{d}$ \\
\hline & June 1993 & $\mathbf{N T}^{c}$ & $<1$ \\
\hline & August 1993 & $<1$ & $<1$ \\
\hline & October 1993 & $<1$ & $<1$ \\
\hline & March 1994 & 5.97 & $<1$ \\
\hline & March 1994 & 18.32 & $\mathrm{NT}^{c}$ \\
\hline & April 1994 & $<1$ & $<1$ \\
\hline & August 1994 & $<1$ & 1.36 \\
\hline & September 1994 & $\mathrm{NT}^{c}$ & $<1$ \\
\hline & October 1994 & $<1$ & $<1$ \\
\hline & March 1995 & $<1$ & $<1$ \\
\hline & May 1995 & $<1$ & $<1$ \\
\hline & August 1995 & $<1$ & $\mathrm{NT}^{c}$ \\
\hline & October 1995 & $<1$ & $\mathrm{NT}^{c}$ \\
\hline & March 1996 & 2.33 & $\mathrm{NT}^{c}$ \\
\hline & March 1996 & $<1$ & $\mathrm{NT}^{c}$ \\
\hline & May 1996 & $<1$ & $\mathrm{NT}^{c}$ \\
\hline
\end{tabular}


Table 2.1 (continued)

\begin{tabular}{|c|c|c|c|}
\hline \multirow{2}{*}{ Outfall } & \multirow{2}{*}{ Test date } & \multicolumn{2}{|c|}{ Chronic toxicity units (TUc) ${ }^{a}$} \\
\hline & & Fathead minnow & Ceriodaphnia \\
\hline \multirow[t]{23}{*}{008} & October 1991 & $\mathrm{ND}^{b}$ & $<1$ \\
\hline & February 1992 & 9.77 & $<1$ \\
\hline & May 1992 & $\mathrm{ND}^{b}$ & $<1$ \\
\hline & August 1992 & $<1$ & $<1$ \\
\hline & October 1992 & $<1$ & $<1$ \\
\hline & February 1993 & $<1$ & $<1$ \\
\hline & May 1993 & $<1$ & $\mathrm{I}^{d}$ \\
\hline & June 1993 & $\mathrm{NT}^{c}$ & $<1$ \\
\hline & August 1993 & $<1$ & $<1$ \\
\hline & October 1993 & 4.08 & $<1$ \\
\hline & December 1993 & $<1$ & $\mathrm{NT}^{c}$ \\
\hline & March 1994 & $<1$ & $<1$ \\
\hline & May 1994 & 1.3 & $<1$ \\
\hline & June 1994 & $<1$ & $\mathrm{NT}^{c}$ \\
\hline & August 1994 & 1.56 & $<1$ \\
\hline & September 1994 & $<1$ & $\mathrm{NT}^{c}$ \\
\hline & October 1994 & $<1$ & $<1$ \\
\hline & March 1995 & $<1$ & $<1$ \\
\hline & May 1995 & $<1$ & $<1$ \\
\hline & August 1995 & $<1$ & $\mathrm{NT}^{c}$ \\
\hline & October 1995 & $<1$ & $\mathrm{NT}^{c}$ \\
\hline & March 1996 & $<1$ & $\mathrm{NT}^{c}$ \\
\hline & May 1996 & $<1$ & $\mathrm{NT}^{c}$ \\
\hline
\end{tabular}


Table 2.1 (continued)

\begin{tabular}{|c|c|c|c|}
\hline \multirow{2}{*}{ Outfall } & \multirow{2}{*}{ Test date } & \multicolumn{2}{|c|}{ Chronic toxicity units (TUc) ${ }^{a}$} \\
\hline & & Fathead minnow & Ceriodaphnia \\
\hline \multirow[t]{23}{*}{009} & October 1991 & $\mathrm{ND}^{b}$ & $<1$ \\
\hline & February 1992 & 7.87 & $<1$ \\
\hline & May 1992 & $<1$ & $<1$ \\
\hline & August 1992 & $<1$ & $<1$ \\
\hline & October 1992 & 2.16 & 1.05 \\
\hline & February 1993 & $<1$ & $<1$ \\
\hline & May 1993 & $<1$ & $\mathrm{I}^{d}$ \\
\hline & June 1993 & $\mathrm{NT}^{c}$ & $<1$ \\
\hline & August 1993 & $<1$ & $<1$ \\
\hline & October 1993 & $<1$ & $<1$ \\
\hline & March 1994 & $<1$ & $<1$ \\
\hline & May 1994 & 1.09 & $<1$ \\
\hline & June 1994 & $<1$ & $\mathrm{NT}^{c}$ \\
\hline & August 1994 & 2.09 & $<1$ \\
\hline & September 1994 & $<1$ & $\mathrm{NT}^{c}$ \\
\hline & October 1994 & 10.73 & $<1$ \\
\hline & November 1994 & 3.38 & $\mathrm{NT}^{c}$ \\
\hline & March 1995 & $<1$ & $<1$ \\
\hline & May 1995 & $<1$ & $<1$ \\
\hline & August 1995 & $<1$ & $\mathrm{NT}^{c}$ \\
\hline & October 1995 & $<1$ & $\mathrm{NT}^{c}$ \\
\hline & March 1996 & $<1$ & $\mathrm{NT}^{c}$ \\
\hline & May 1996 & $<1$ & $\mathbf{N T}^{c}$ \\
\hline
\end{tabular}


Table 2.1 (continued)

\begin{tabular}{|c|c|c|c|}
\hline \multirow{2}{*}{ Outfall } & \multirow{2}{*}{ Test date } & \multicolumn{2}{|c|}{ Chronic toxicity units (TUc) ${ }^{a}$} \\
\hline & & Fathead minnow & Ceriodaphnia \\
\hline \multirow[t]{12}{*}{011} & October 1991 & $\mathrm{ND}^{b}$ & $<1$ \\
\hline & February 1992 & 7.69 & $<1$ \\
\hline & May 1992 & $\mathrm{ND}^{b}$ & $<1$ \\
\hline & August 1992 & $<1$ & $<1$ \\
\hline & October 1992 & $<1$ & $<1$ \\
\hline & February 1993 & $<1$ & $<1$ \\
\hline & May 1993 & $<1$ & $<1$ \\
\hline & August 1993 & $<1$ & $<1$ \\
\hline & October 1993 & $<1$ & $<1$ \\
\hline & March 1994 & 23.53 & $<1$ \\
\hline & March 1994 & 32.57 & $\mathrm{NT}^{c}$ \\
\hline & April 1994 & $<1$ & $<1$ \\
\hline \multirow[t]{9}{*}{010} & August 1994 & $<1$ & $<1$ \\
\hline & October 1994 & $<1$ & $<1$ \\
\hline & March 1995 & $<1$ & $<1$ \\
\hline & May 1995 & $<1$ & $<1$ \\
\hline & August 1995 & $<1$ & $\mathrm{NT}^{c}$ \\
\hline & October 1995 & $<1$ & $\mathrm{NT}^{c}$ \\
\hline & March 1996 & 8.62 & $\mathrm{NT}^{c}$ \\
\hline & March 1996 & $<1$ & $\mathrm{NT}^{c}$ \\
\hline & May 1996 & $<1$ & $\mathrm{NT}^{c}$ \\
\hline
\end{tabular}

${ }^{a}$ Chronic toxicity unit $=100 / \mathrm{IC} 25 ; \mathrm{IC} 25=$ the concentration causing a $25 \%$ reduction in fathead minnow growth or Ceriodaphnia reproduction.

${ }^{b} \mathrm{ND}=$ not determined.

'NT = not tested.

$d_{1}=$ invalid test due to low reproduction in the control water.

Effluent from the C-617 lagoon was diverted from Outfall 011 to Outfall 010 during June 1994. As a result, effluent from Outfall 010 instead of Outfall 011 was tested after June 1994. Outfall 010 includes discharges from outfalls 002,011 , and 012 during normal plant operations. 
Table 2.2. Results of effluent biomonitoring tests for intermittent outfalls $013,015,016,017$, and 018

\begin{tabular}{|c|c|c|c|}
\hline \multirow{2}{*}{ Outfall } & \multirow{2}{*}{ Test date } & \multicolumn{2}{|c|}{ Chronic toxicity units (TUc) ${ }^{a}$} \\
\hline & & Fathead minnow & Ceriodaphnia \\
\hline \multirow[t]{19}{*}{013} & December 1991 & $<1$ & $<1$ \\
\hline & March 1992 & 5.82 & $<1$ \\
\hline & June 1992 & 1.02 & $<1$ \\
\hline & September 1992 & $<1$ & $<1$ \\
\hline & November 1992 & 1.96 & $<1$ \\
\hline & January 1993 & $<1$ & 6.99 \\
\hline & May 1993 & 1.3 & $<1$ \\
\hline & September 1993 & 1.39 & $<1$ \\
\hline & November 1993 & $<1$ & $<1$ \\
\hline & February 1994 & 11.31 & 1.04 \\
\hline & April 1994 & $<1$ & $<1$ \\
\hline & September 1994 & $<1$ & $<1$ \\
\hline & November 1994 & $<1$ & $<1$ \\
\hline & January 1995 & $<1$ & $<1$ \\
\hline & April 1995 & $<1$ & $<1$ \\
\hline & July 1995 & $<1$ & $<1$ \\
\hline & November 1995 & $<1$ & $<1$ \\
\hline & January 1996 & $<1$ & 34.60 \\
\hline & April 1996 & $<1$ & $\mathrm{NT}^{c}$ \\
\hline
\end{tabular}


Table 2.2 (continued)

\begin{tabular}{|c|c|c|c|}
\hline \multirow{2}{*}{ Outfall } & \multirow{2}{*}{ Test date } & \multicolumn{2}{|c|}{ Chronic toxicity units (TUc) ${ }^{a}$} \\
\hline & & Fathead minnow & Ceriodaphnia \\
\hline \multirow[t]{19}{*}{015} & December 1991 & $<1$ & $<1$ \\
\hline & March 1992 & 7.91 & $<1$ \\
\hline & June 1992 & $<1$ & $<1$ \\
\hline & September 1992 & $<1$ & $\mathrm{ND}^{b}$ \\
\hline & November 1992 & $<1$ & $<1$ \\
\hline & January 1993 & 1.52 & $<1$ \\
\hline & May 1993 & 3.62 & $<1$ \\
\hline & September 1993 & $<1$ & $<1$ \\
\hline & November 1993 & $<1$ & $<1$ \\
\hline & February 1994 & 2.04 & $<1$ \\
\hline & April 1994 & 11.15 & $<1$ \\
\hline & September 1994 & $<1$ & $<1$ \\
\hline & November 1994 & 17.54 & $<1$ \\
\hline & January 1995 & $<1$ & $<1$ \\
\hline & April 1995 & $<1$ & $<1$ \\
\hline & July 1995 & $<1$ & $<1$ \\
\hline & October 1995 & $<1$ & $<1$ \\
\hline & Jamuary 1996 & $<1$ & $<1$ \\
\hline & April 1996 & $<1$ & $\mathrm{NT}^{c}$ \\
\hline
\end{tabular}


Table 2.2 (continued)

\begin{tabular}{|c|c|c|c|}
\hline \multirow{2}{*}{ Outfall } & \multirow{2}{*}{ Test date } & \multicolumn{2}{|c|}{ Chronic toxicity units (TUc) ${ }^{a}$} \\
\hline & & Fathead minnow & Ceriodaphnia \\
\hline \multirow[t]{18}{*}{016} & December 1991 & $<1$ & $<1$ \\
\hline & March 1992 & 1.74 & $<1$ \\
\hline & September 1992 & $<1$ & $<1$ \\
\hline & November 1992 & 1.32 & $<1$ \\
\hline & January 1993 & 2.04 & $<1$ \\
\hline & May 1993 & $<1$ & $<1$ \\
\hline & September 1993 & $<1$ & $<1$ \\
\hline & November 1993 & $<1$ & $<1$ \\
\hline & February 1994 & $<1$ & $<1$ \\
\hline & April 1994 & $<1$ & $<1$ \\
\hline & September 1994 & $<1$ & $<1$ \\
\hline & November 1994 & 23.47 & $<1$ \\
\hline & January 1995 & $<1$ & $<1$ \\
\hline & April 1995 & $<1$ & $<1$ \\
\hline & July 1995 & $<1$ & $<1$ \\
\hline & November 1995 & $<1$ & $<1$ \\
\hline & January 1996 & $<1$ & $<1$ \\
\hline & April 1996 & $<1$ & $\mathrm{NT}^{c}$ \\
\hline
\end{tabular}


Table 2.2 (continued)

\begin{tabular}{|c|c|c|c|}
\hline \multirow{2}{*}{ Outfall } & \multirow{2}{*}{ Test date } & \multicolumn{2}{|c|}{ Chronic toxicity units (TUc) ${ }^{a}$} \\
\hline & & Fathead minnow & Ceriodaphnia \\
\hline \multirow[t]{19}{*}{017} & December 1991 & $\mathrm{ND}^{b}$ & $<1$ \\
\hline & March 1992 & 4.54 & $<1$ \\
\hline & June 1992 & $<1$ & $<1$ \\
\hline & September 1992 & 5.01 & $<1$ \\
\hline & November 1992 & $<1$ & $<1$ \\
\hline & January 1993 & $<1$ & $<1$ \\
\hline & May 1993 & 23.8 & $<1$ \\
\hline & September 1993 & $<1$ & $<1$ \\
\hline & November 1993 & $<1$ & $<1$ \\
\hline & February 1994 & 2.83 & $<1$ \\
\hline & April 1994 & 1.79 & $<1$ \\
\hline & September 1994 & $<1$ & $<1$ \\
\hline & November 1994 & 66.23 & $<1$ \\
\hline & January 1995 & $<1$ & $<1$ \\
\hline & April 1995 & $<1$ & $<1$ \\
\hline & July 1995 & $<1$ & $<1$ \\
\hline & November 1995 & $<1$ & $<1$ \\
\hline & January 1996 & $<1$ & 25.91 \\
\hline & April 1996 & $<1$ & $\mathrm{NT}^{c}$ \\
\hline
\end{tabular}


Table 2.2 (continued)

\begin{tabular}{|c|c|c|c|}
\hline \multirow{2}{*}{ Outfall } & \multirow{2}{*}{ Test date } & \multicolumn{2}{|c|}{ Chronic toxicity units (TUc) ${ }^{a}$} \\
\hline & & Fathead minnow & Ceriodaphnia \\
\hline \multirow[t]{19}{*}{018} & December 1991 & $<1$ & $<1$ \\
\hline & March 1992 & 5.27 & $<1$ \\
\hline & June 1992 & $<1$ & $<1$ \\
\hline & September 1992 & $<1$ & $<1$ \\
\hline & November 1992 & 1.43 & $<1$ \\
\hline & January 1993 & 8.47 & $<1$ \\
\hline & May 1993 & 21.7 & $<1$ \\
\hline & September 1993 & $<1$ & $<1$ \\
\hline & November 1993 & $<1$ & $<1$ \\
\hline & February 1994 & $<1$ & $<1$ \\
\hline & April 1994 & 1.39 & $<1$ \\
\hline & September 1994 & $<1$ & 3.47 \\
\hline & November 1994 & $<1$ & $<1$ \\
\hline & January 1995 & $<1$ & 1.01 \\
\hline & April 1995 & 1.87 & $<1$ \\
\hline & July 1995 & $<1$ & $<1$ \\
\hline & November 1995 & $<1$ & $<1$ \\
\hline & January 1996 & $<1$ & 6.73 \\
\hline & April 1996 & $<1$ & $\mathrm{NT}^{c}$ \\
\hline
\end{tabular}

${ }^{a}$ Chronic toxicity unit $=100 / \mathrm{IC} 25 ; \mathrm{IC} 25=$ the concentration causing a $25 \%$ reduction in fathead minnow growth or Ceriodaphnia reproduction.

${ }^{b} \mathrm{ND}=$ not determined.

TT $=$ not tested. 
Table 2.3. Number of permit exceedances from the KPDES permit (from Nov. 1, 1992, through Feb. 29, 1996) for PGDP outfalls

\begin{tabular}{|c|c|c|c|c|c|c|c|}
\hline \multirow{2}{*}{ Outfall } & \multicolumn{6}{|c|}{ Metal } & \multirow{2}{*}{$\begin{array}{l}\text { Total per } \\
\text { outfall }\end{array}$} \\
\hline & $\mathrm{Cd}$ & $\mathrm{Ni}$ & $\mathrm{Pb}$ & $\mathrm{Zn}$ & $\mathrm{Cu}$ & $\mathrm{Cr}$ & \\
\hline \multicolumn{8}{|l|}{ Continuous Outfalls } \\
\hline 001 & 0 & 0 & 0 & 0 & 0 & 0 & 0 \\
\hline 006 & \multicolumn{6}{|c|}{ No permit limits; metal concentrations are report only. } & NA \\
\hline 008 & 2 & 0 & 2 & 0 & 5 & 0 & 9 \\
\hline 009 & 2 & 0 & 3 & 3 & 5 & 0 & 13 \\
\hline $\begin{array}{c}010 / 011 \\
\text { (C-617 discharge) }\end{array}$ & 0 & 0 & 5 & 2 & 5 & 0 & 12 \\
\hline \multicolumn{8}{|l|}{ Intermittent Outfalls } \\
\hline $002^{a}$ & 0 & 0 & 4 & 0 & 7 & 0 & 10 \\
\hline 003 & \multicolumn{6}{|c|}{ No discharge since $11 / 1 / 92$} & NA \\
\hline $011^{a}$ & 0 & 0 & 0 & 0 & 3 & 0 & 3 \\
\hline $012^{a}$ & 0 & 0 & 1 & 14 & 4 & 4 & 23 \\
\hline 013 & 0 & 0 & 2 & 0 & 2 & 0 & 4 \\
\hline 015 & 0 & 0 & 1 & 0 & 0 & 0 & 1 \\
\hline 016 & 0 & 0 & 1 & 2 & 0 & 0 & 3 \\
\hline 017 & 2 & 0 & 2 & 0 & 1 & 0 & 5 \\
\hline 018 & 0 & 1 & 3 & 0 & 10 & 4 & 18 \\
\hline Total by metal & 6 & 1 & 23 & 21 & 42 & 8 & 101 \\
\hline
\end{tabular}

${ }^{a}$ Storm water exceedances.

Source: C. C. Travis, LMUS, personal communication.

\subsection{OBJECTIVES}

EPA policy recommends that the concentration of dissolved (rather than TR) metal be used to set and measure compliance with water quality standards, because dissolved metal more closely estimates the bioavailable fraction of metal in the water column than does TR metal (EPA 1995). The bioavailable or dissolved fraction of metal present will be the most 
likely source of toxicity to aquatic animals because dissolved metal is more readily adsorbed at the cellular surfaces (e.g., gill surface). While particle associated metal cannot be considered nontoxic, it does appear to exhibit substantially less toxicity than dissolved metal (EPA 1995). Part of what is measured as dissolved-defined as that which passes through a $0.45-\mu \mathrm{m}$ filter - is adsorbed to or complexed with organic colloids and ligands; which may be biologically unavailable. By regulation [40 CFR 122.45 (c)], the permit limit, in most cases, must be expressed as TR metal. To express the criteria as dissolved metal, a conversion factor is applied to account for the particulate metal present.

Following the KDOW method, effluent samples will be collected concurrently for biomonitoring and chemical analysis to evaluate the protectiveness of the aquatic environment. Biomonitoring of the effluent is required to evaluate potential exposure and effects from contaminants. Analytical data will be used to determine the relationship between the TR and dissolved metal fractions for each metal included in the study. The biomonitoring and analytical data will be used to meet the objectives of this study:

1. Evaluate the toxicity of continuous and intermittent outfalls at PGDP.

2. Determine whether the concentration of TR metal discharged is toxic to fathead minnows and/or Ceriodaphnia.

3. Determine the mean ratio of dissolved to TR metal in the continuous and intermittent outfalls.

4. Recommend alternative metal limits for each metal of concern.

While the KDOW method (developed to determine alternative metal limits) will be followed, PGDP reserves the right to develop alternative metal limits for its permitted outfalls using the EPA water-effect ratio approach. Data collected for this study may be used to evaluate the appropriateness of determining the WER for each outfall of concern.

\section{SITE DESCRIPTION}

The PDGP is owned by DOE. In July 1993, DOE leased the plant production operations facilities, which are managed by Lockheed Martin Utility Systems, Inc. (LMUS), to USEC. Under this lease, USEC has assumed responsibility for compliance activities directly associated with uranium enrichment operations. The environmental restoration and waste management activities are managed by Lockheed Martin Energy Systems, Inc. (LMES). Construction of the plant was completed in 1954, although production of uranium began in 1952. PGDP is an active uranium enrichment facility consisting of a diffusion cascade and extensive support facilities. The uranium enrichment gaseous diffusion process involves more than 1800 stages with operations housed in 5 buildings covering $\sim 300$ ha. Including support

facilities, the plant has $\sim 30$ permanent buildings located on a 1385-ha site. Support facilities include a steam plant, four electrical switchyards, four sets of cooling towers, a chemical cleaning and decontamination facility, water and wastewater treatment plants, a chromium reduction facility, and maintenance and laboratory facilities. Several inactive facilities are also located on the site. Currently, the Paducah cascade processes are being used for the 
enrichment of uranium to $2 \%{ }^{235} \mathrm{U}$. This product is then transferred to the Portsmouth (Ohio) Gaseous Diffusion Plant for further enrichment. Most of the uranium produced is used commercial reactors in the United States or abroad (Kszos 1996).

\section{TECHNICAL SPECIFICATIONS}

The work plan is designed to follow guidance from the KDOW for determining alternative metal limits and thus will require collection of data on effluent toxicity and concentrations of TR and dissolved metals.

\subsection{MONITORING SCHEDULE}

Sampling and analysis will be conducted in two phases. Alternative metals limits for the continuously discharging outfalls $(001,008,009$, and 010) will be determined in Phase I and for the intermittently discharging outfalls $(003,013,015,016,017$, and 018) in Phase II. If, prior to implementation of the schedules set forth, KDOW issues to PGDP a new KPDES permit that includes metals limits, and such limits are not challenged by PGDP, then all activities scheduled to be completed in Phase II will be canceled and PGDP will meet the limits established in the new KPDES permit. In each phase, samples will be evaluated for toxicity and TR and dissolved metals will be measured.

Phase I activities will be initiated no later than 60 days following approval of the work plan by KDOW.

\subsection{MONITORING DURATION}

During Phase I, six biomonitoring tests of each continuous outfall will be conducted over a period of one year. This schedule will assure that temporal variations in the chemical properties of the effluent and other environmental conditions are taken into account.

The physico-chemical properties of the effluent (e.g., temperature, $\mathrm{pH}$, alkalinity, dissolved oxygen, hardness, and total suspended solids) will determine the fraction of metal that is dissolved and the fraction that is in particulate form. Biomonitoring tests of intermittent outfalls will be conducted following a similar schedule. Phase II sampling activities will not begin until completion of Phase I and approval by PGDP and KDOW.

\subsection{SAMPLE COLLECTION AND PROCESSING}

For this study, samples for biomonitoring tests and chemical analyses will be collected concurrently from each effluent. Under Phase I, three 24-h composite samples from outfalls $001,008,009$, and 010 or 011 (whichever is running) will be collected during each 7-d test period. A total of 18 samples from each continuous outfall will be collected and evaluated for toxicity and for determination of mean metals concentrations. Under Phase II, one grab sample from intermittent outfalls that exhibit metals or toxicity problems will be collected and 
evaluated for toxicity and for measuring metals concentrations. A total of six samples will used to determine the mean ratio of dissolved to TR metal in the intermittent outfalls.

Collection procedures must not alter the effluent sampled. The potential for contamination during sample collection and sample processing will be minimized by use of EPA “clean" techniques and by minimizing sample handling. Studies have shown that metals concentrations in EPA and U. S. Geological Survey databases and in effluent discharges may be largely the result of sample contamination rather than actual sample concentration. The use of clean techniques have resulted in fewer noncompliances (EPA 1996).

Samples will be collected in acid-cleaned or precleaned plastic containers, such as highdensity polyethylene or polypropylene. Unnecessary exposure of the sample to the atmosphere will be avoided to reduce the potential for contamination from atmospheric particulates.

Any sampling devices used will be constructed of nonmetallic material or, at a minimum, all water contact surfaces will be constructed of nonmetallic material.

Until analysis by the analytical laboratory, any metals concentrations in the samples must be maintained as close as possible to the same levels as they were in the environment from which they were collected. For dissolved metal determinations, samples must be filtered through a $0.45-\mu \mathrm{m}$ membrane or capsule filter. To minimize exposure, field preservation and filtration will be performed inside a field-portable glove bag or in a designated clean area. Effluent samples for TR and dissolved metals analyses will be preserved with $10 \% \mathrm{HNO}_{3}$ to $\mathrm{pH}<2$.

A minimum two-person sampling team is required. All sampling personnel must wear clean, non-talc gloves and may need to wear disposable nylon coveralls or windsuits to prevent sample contamination.

At the time of sample collection, the flow from the outfalls will be measured and recorded. Testing of the effluents will be initiated within $36 \mathrm{~h}$ of sample collection. Samples collected for metals analyses will be segregated from samples used to conduct biomonitoring tests. Preserved samples will be stored and shipped on ice to the analytical laboratory. Samples for toxicity testing will be packed in coolers with sufficient ice to keep the samples at approximately $4 \pm 2{ }^{\circ} \mathrm{C}$ and shipped to the Aquatic Toxicology Laboratory.

The sampling team may modify the sampling techniques described in the Sampling and Analysis Plan (SAP) to improve performance or reduce sampling costs, provided that samples and blanks are not contaminated or altered. Any modifications to procedures contained in the SAP must be documented and approved by the Project Manager.

\subsection{SAMPLE CUSTODY}

Each sample will be shipped with chain-of-custody (COC) forms generated by the field sampling personnel, documenting custody of each sample. Samples will be received in the Aquatic Toxicology Laboratory and analytical laboratory with appropriate COC documents and analysis request forms. Upon receipt, the Aquatic Toxicology Laboratory will immediately store the samples in the dark at $4 \pm 2{ }^{\circ} \mathrm{C}$. Chain of custody will be maintained by the Toxicology Laboratory until final disposition of the samples. 


\subsection{BIOMONITORING}

Chronic, static-renewal biomonitoring tests using fathead minnow ( $P$. promelas) larvae and $C$. dubia will be conducted according to technical procedures described in the Toxicology Laboratory Quality Assurance Program manual (Kszos et al. 1989). Toxicity test procedures are based on EPA methodology (Methods 1000.0, Fathead Minnow Larval Survival and Growth Test, and 1002.0, C. dubia Survival and Reproduction Test) (Lewis 1994).

The fathead minnow test will consist of four replicates per test concentration with 10 larvae per replicate. The number of larvae surviving will be recorded daily. At the end of the test period $(7 \mathrm{~d})$, the larvae will be dried and weighed to estimate growth. The Ceriodaphnia test will consist of 10 replicates per test concentration with one animal per replicate. Survival and the number of offspring will be recorded daily for each animal.

Any toxic effects will include the synergistic, antagonistic, and additive effects of all chemical and physical components of the effluent which adversely affect the physiological and biochemical functions of the test organisms.

All biomonitoring tests will be conducted by qualified personnel in the Aquatic Toxicology Laboratory

\subsection{LABORATORY ANALYSIS OF TOTAL RECOVERABLE AND DISSOLVED METALS}

To achieve low detection limits, the EPA recommends that trace metals analyses be performed using inductively coupled plasma/mass spectrometry (ICP/MS) (EPA 1994b). Therefore, concentrations of TR and dissolved $\mathrm{Cd}, \mathrm{Cu}, \mathrm{Cr}, \mathrm{Pb}, \mathrm{Ni}$, and $\mathrm{Zn}$ in each outfall will be determined using ICP/MS (EPA Method 200.8). Based on compliance history for Outfall 001 , analysis of hexavalent chromium will not be included in the work plan.

All metals of interest $-\mathrm{Cd}, \mathrm{Cu}, \mathrm{Cr}, \mathrm{Pb}, \mathrm{Ni}$, and $\mathrm{Zn}-$ can be analyzed simultaneously from a single effluent sample using ICP/MS. The target Method Detection Limits (MDLs) should be one third of the regulatory compliance limit.

Metals analyses will be performed by competent analysts using clean techniques. The analytical laboratory should meet the requirements established under the EPA Contract Laboratory Program (CLP). The laboratory must be able to demonstrate capability to perform method 200.8. Inadvertent contamination could be introduced during sample preparation and analysis, therefore, the laboratory should have a trace metal clean room. The basic requirements for a trace metal clean room are: (1) metal free work surfaces and hoods, (2) positive pressure with HEPA-filtered air, and (3) ultrapure water. Laboratory qualifications will be evaluated and determined by the Technical Subcontracting Office (TSO).

\subsection{ADDITIONAL PHYSICAL/CHEMICAL ANALYSES}

The chemical properties of the effluent will determine the fraction of the metal that is in the dissolved and particulate phases. Different factors influence the dissolved to TR metal ratio such as water temperature, $\mathrm{pH}$, total hardness, concentrations of metal binding sites (i.e., concentrations of total suspended solids), dissolved organic carbon, as well as concentrations of other metals and organic compounds that compete with metal ions for binding sites (EPA 1995a). A portion of each effluent sample will be saved for measurement 
of total suspended solids. Measurement of dissolved organic carbon will not be performed initially; a decision to include this analysis will be made after reviewing initial testing and metals data.

Analysis of $\mathrm{pH}$, conductivity, alkalinity, hardness, and dissolved oxygen will be made in the high, middle, and low toxicity test concentrations for each new effluent sample. Dissolved oxygen and $\mathrm{pH}$ will also be measured each day before test water renewal.

\subsection{MEASUREMENT ENDPOINTS}

Using the method developed by the KDOW, data collected and analyzed for this study will be used to recommend alternative metals limits for the outfalls. The measurement endpoints for this study are as follows:

- Measurement endpoint 1: determine the inhibition concentration (i.e., $\mathrm{IC}_{25}$; the concentration that causes a $25 \%$ reduction in fathead minnow growth or Ceriodaphnia reproduction).

- Measurement endpoint 2: determine the chronic toxicity unit (TUc) derived (TUc = $\left.100 / \mathrm{IC}_{25}\right)$ to evaluate effluent toxicity to fathead minnows or Ceriodaphnia.

- Measurement endpoint 3: determine the TR and dissolved metal concentrations for each outfall sampled.

- Measurement endpoint 4: determine the mean dissolved:TR ratio for each metal of concern in each outfall.

- Measurement endpoint 5: use the following equation (from KDOW method) to evaluate whether measured metal concentrations would comply with permit limits expressed as TR:

Metal concentration of effluent sampled $=($ TR metal of effluent $\times$ dissolved:TR ratio $)$ $\times 1$ /EPA criteria conversion factor for dissolved metals

Criteria conversion factors for dissolved metals were developed by the EPA. Final factors were published in the Federal Register on May 4, 1995 (EPA 1995c). For this study, the EPA freshwater chronic conversion factors in Table 4.1 will be applied to measurement endpoint 5. Chronic conversion factors for any hardness can be calculated using the following equations (EPA 1995c):

Cadmium: $\quad \mathrm{CF}=1.101672-[(\ln$ hardness $)(0.041838)]$

Lead: $\quad C F=1.46203-[($ In hardness $)(0.145712)]$ 
Table 4.1. EPA freshwater chronic conversion factors

\begin{tabular}{cc}
\hline Metal & Chronic conversion factor \\
\hline Cadmium & $0.909^{a}$ \\
Chromium VI & 0.962 \\
Copper & 0.960 \\
Lead & $0.791^{a}$ \\
Nickel & 0.997 \\
Zinc & 0.986 \\
\hline
\end{tabular}

${ }^{a}$ Conversion factors are hardness dependent. The values shown are for a hardness of $100 \mathrm{mg} / \mathrm{L}$ as $\mathrm{CaCO}_{3}$.

\section{QUALITY ASSURANCE/QUALITY CONTROL}

The QA objectives for the bioavailability study data are the following:

- Scientific data generated will withstand scientific scrutiny,

- Data will be gathered using controlled, approved procedures for field sampling, chainof-custody, and laboratory analyses, and

- Data will be of known precision and accuracy.

The QA objective for all data collected for the bioavailability study is to obtain measurements that are reproducible, precise, and accurate and are consistent with the intended use of the data and the limitations of the sampling and analytical methods used. The objective for completeness - the amount of valid data obtained from the sampling and analytical process-is $95 \%$ of the planned samples. Completeness of sample collection will be measured by comparing the number of samples planned versus the number collected and submitted for analysis. Completeness-for field QC purposes-will be made by comparing samples submitted for a particular analysis with samples rejected because of errors in collection, processing, preservation, or other field or laboratory related activities.

The sampling and analysis of effluent samples will be performed following approved procedures to ensure the highest quality, accountability, and traceability of data in sampling, analysis, and reporting activities. Quality assurance is achieved through management, planning and control of work processes, establishing performance criteria, assessing achievement of quality criteria, evaluating technical capabilities, and ensuring the traceability of data.

\subsection{QUALITY CONTROL SAMPLE CHECKS}

Quality control (QC) sample checks are used to (1) monitor sample collection and sample handling techniques; (2) evaluate sampling equipment and sample container decontamination 
procedures; (3) assess the sensitivity of the test organisms and the credibility of the test system; (4) measure the precision of analytical methods; (5) evaluate contamination introduced during sample collection, processing, and analysis; and (6) document equipment calibration. These checks may include, but are not limited to, field blanks, field duplicates, replicates, controls, equipment rinse blanks, matrix spikes, preservative blanks, and certified reference standards for equipment calibration.

\subsubsection{Field Data Quality}

Field QC includes, but is not limited to sample collection, custody, processing, preservation, container selection, transport, and field record keeping. These activities will be performed following procedures contained in the ESD Toxicology Laboratory Quality Assurance Program Plan, the work plan, or in the SAP.

Sample custody will be established by the sampling personnel at the time of sample collection through the use of chain-of-custody forms. Custody will be maintained throughout sample processing and delivery to the analytical laboratory.

Quality control samples will be collected to address field quality as it relates to precision, representativeness, comparability, and completeness. Field QC samples will include field splits, equipment rinse blanks, field rinse water blanks, and filter blanks, as appropriate. Field QC samples will be treated identically to routine samples in terms of sample identification, sample custody, sample processing, request for analytical services, and data processing.

- Field splits will be collected for analysis of TR or dissolved metals at the rate of one per sampling location per test period. These samples will be used to evaluate the precision of the laboratory analysis. The level of precision will be judged acceptable if the relative percent difference (RPD) is $\leq 20 \%$.

- Equipment rinse blanks will be collected from each automatic sampler unit before the first effluent sample from each location is collected. These samples will be used to evaluate the adequacy of the decontamination process.

- Presterilized filter units will be used to process field collected samples for analysis of dissolved metals. Filter (field) blanks will be collected at the rate of one per lot used or one per sampling location, whichever is less.

- Rinse water blanks will consist of ASTM Type II water or equivalent. This water will be used to collect filter blanks, equipment rinse blanks, sampler unit bottle blanks, and for rinsing automatic sampler unit bottles between sample collection. A rinse water sample will be collected at the rate of one per batch of water used.

\subsubsection{Analytical Data Quality}

Quality control requirements for the analytical laboratory are Level 3. Level $3 \mathrm{QC}$ provides low detection limits, a range of calibrated analytes, laboratory process control 
information, and known precision and accuracy. Laboratory control samples should include, but not be limited to, method blanks, matrix spikes, and matrix spike duplicates.

- Method blanks will be evaluated to assess contamination introduced during different phases of sample processing and analysis. Blanks may include calibration blanks and laboratory blanks.

- The accuracy of the analytical method and potential matrix effects will be assessed by analyzing matrix spikes (MS) and matrix spike duplicates (MSD). At least one MS/MSD will be analyzed per sample batch (samples collected from the same site during each test period).

Method detection limits for each analyte will be determined according to the procedure in 40 CFR 136, Appendix B, using the apparatus, reagents, and standards that will be used in Method 200.8. MDLs should be determined when a new analyst begins work or, in the judgment of the analyst, when a change in instrument hardware or operating conditions would dictate that they be redetermined. At a minimum, the MDL will be one-third of the lowest regulatory compliance limit for each metal of concern.

Sample holding times will begin on the day of sample collection. Holding time ends when the analysis, resulting in reportable data, has been initiated. The maximum allowable holding time is $180 \mathrm{~d}$ for preserved samples.

Additional Level 3 QA requirements may include, but are not limited to, the evaluation of the following:

- Initial and continuing instrument calibration. The instrument should be calibrated a minimum of three points for each analyte to be determined. The correlation coefficient should be $>0.990$.

- ICP interference checks. Interference sample checks should be run at the beginning and at the end of each sample analysis run. The results should be within $\pm 20 \%$ of the true value.

- Initial and ongoing precision and recovery. Aliquots of reagent grade water will be spiked with the metal(s) of interest. These samples will be subjected to all steps in the analytical process, including digestion, extraction, and concentration, as applicable. The average percent recovery and the standard deviation of the recovery for each metal should be reported.

The TSO is responsible for the procurement and approval of subcontractors for direct analytical support. TSO approval covers analytical methods, QA/QC requirements, deliverables, appropriateness of the laboratory to accomplish the work, and any other requirements of the analytical plan. The TSO is responsible for assessing the laboratory to ensure compliance with quality and technical standards. 


\subsubsection{Toxicity Data Quality}

Reference toxicant tests will be conducted to assess the sensitivity of the test organisms and the overall credibility of the test method. The tests will use the same organisms and control media and be performed under the same conditions as the biomonitoring tests commonly performed by the testing laboratory. Reference toxicant tests using fathead minnow larvae and $C$. dubia will be conducted monthly.

Additional data quality and test requirements are specified in the ESD Toxicology Laboratory Quality Assurance Program Plan, in standard operating procedures, and in the EPA test methods. These requirements include, but are not limited to, instrument calibration and verification, test temperature, food volumes, feeding intervals, and test organism age.

Any variations in the test method will be documented in accordance with the ESD Toxicology Laboratory Quality Assurance Program Plan.

\subsection{ANALYTICAL DATA DELIVERABLES}

Data deliverables from the analytical laboratory will be Level 3. Both hard copy and electronic data transmission will be required. The turnaround time for data deliverables is 30 days from sample receipt. The data set deliverables should include the following information, as appropriate.

- Sample identification numbers,

- Batch number identifiers,

- Holding time information,

- Digestion date(s),

- Analysis date(s),

- Discussion of laboratory analysis (including problems encountered and corrective actions taken),

- Results of laboratory control samples,

- Sample results (reported in $\mu \mathrm{g} / \mathrm{L}$ ),

- Initial and continuing calibration (including dates of analyses, calibration curves, and correlation coefficients),

- Analysis of method blanks,

- ICP interference checks, and

- Sample spike recovery.

\subsection{INCORPORATION OF EPA “CLEAN" TECHNIQUES}

Because metals data are used to estimate effluent concentrations (i.e., daily maximums and monthly averages) and determine compliance with permit limits, the quality of the data is an important issue. Therefore the EPA recommends the use of "clean" techniques for collecting and analyzing samples for metals analyses.

EPA Method 1669 (EPA 1995b) was developed for the collection and filtration of ambient water samples for determination of TR and dissolved metals at levels substantially below the ambient WQC. This method, however, was not intended for use in the determination of metals at concentrations that are normally found in treated and untreated 
industrial discharges. Metal concentrations in ambient water are normally in the low partsper-trillion (ppt) to low parts-per-billion (ppb) range; whereas, metal concentrations in industrial effluents are normally found in the high ppb range.

Every effort will be made to avoid contamination by incorporating "clean" techniques within the limitations of the sampling and analytical methods. The general principles of contamination control, as they apply to this bioavailability study, include the following:

- Using non-talc gloves during sample collection and processing activities for handling sampling equipment and sample bottles.

- Using preclean, disposable, or acid-cleaned sample containers and filter units.

- Decontaminating sampling equipment prior to initial sample collection.

- Using reagent grade, trace-metals-free preservatives.

- Properly storing cleaned sampling equipment and sample bottles to prevent exposure to atmospheric particulates.

- Using ASTM II Type water or equivalent (i.e., deionized distilled water).

- Using metal free work surfaces and fume hoods.

- Maintaining clean work surfaces and work areas.

Specific instructions for controlling contamination will be contained in the SAP for field sampling and field processing activities. Instructions for contamination control, as they apply to the analytical laboratory, will be identified in the analytical Statement of Work.

Results of the analysis of quality control samples will be used to assess the effectiveness of contamination control measures and the overall impact on sample results.

\section{TOXICITY IDENTIFICATION EVALUATION}

According to the KDOW Procedures to Facilitate Alternative Metals Limits, a toxicity identification evaluation (TIE) will be required in the event of failure of two biomonitoring tests.

Effluent toxicity may be caused by certain cationic metals (e.g., copper, lead, nickel, zinc). The addition of a chelating agent to an effluent sample may provide information concerning the category of toxicant present if toxicity is observed; therefore, a subsample of full-strength effluent used to conduct the biomonitoring tests will be treated with ethylenediaminetetraacetate (EDTA). The EDTA-treated samples will be evaluated using fathead minnow larvae and Ceriodaphnia. Data obtained from the EDTA-treated effluent biomonitoring tests as well as chemical analyses may be used as part of a TIE. 


\section{SCHEDULE OF DELIVERABLES}

The schedule in Table 7.1 allows for completion of 7-d biomonitoring tests and chemical analyses for each phase of the study. Data in the final reports will be used to recommend alternative metal limits for the outfalls.

Table 7.1. Deliverables for study

\begin{tabular}{ll}
\hline \multicolumn{1}{c}{ Activity } & \multicolumn{1}{c}{ Status } \\
\hline Initiation of Phase I & $\begin{array}{l}\text { No later than } 60 \text { days following approval of the } \\
\text { work plan by the State. } \\
\text { No later than } 12 \text { months following initiation of } \\
\text { Phase I activities. }\end{array}$ \\
Completion of Phase I & $\begin{array}{l}\text { Submitted to PGDP no later than } 60 \text { days } \\
\text { following results of Phase I sampling and } \\
\text { analytical activities. }\end{array}$ \\
Final Report - Phase I & $\begin{array}{l}\text { Submitted to KDOW no later than } 30 \text { days } \\
\text { following receipt of comments on the Phase I draft } \\
\text { report. }\end{array}$ \\
Initiation of Phase II & $\begin{array}{l}\text { No later than } 60 \text { days following approval of the } \\
\text { Phase I draft report by KDOW. }\end{array}$ \\
Completion of Phase II & $\begin{array}{l}\text { No later than } 12 \text { months following initiation of } \\
\text { Phase II activities. }\end{array}$ \\
Draft Report - Phase II & $\begin{array}{l}\text { Submitted to PGDP no later than } 60 \text { days } \\
\text { following results of Phase II sampling and } \\
\text { analytical activities. }\end{array}$ \\
Final Report - Phase II & $\begin{array}{l}\text { Submitted to KDOW no later than } 30 \text { days } \\
\text { following receipt of comments on the Phase II } \\
\text { draft report. }\end{array}$ \\
\hline
\end{tabular}

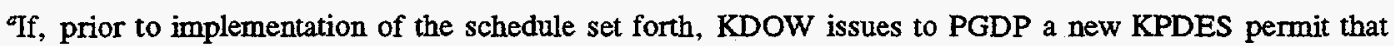
includes metals limits and such limits are not challenged by PGDP, then all activities scheduled to be completed in Phase II will be canceled and PGDP will meet the limits established in the new KPDES permit. 


\section{REFERENCES}

Kszos, L.A., A. J. Stewart, L. F. Wicker, L. E. Roberson, and T. L. Phipps. 1989. Oak Ridge National Laboratory, Environmental Sciences Division, Toxicology Laboratory Quality Assuranice Program. QAP-X-89-ES-002.

Kszos, L. A. (ed.) 1996. Report of the Biological Monitoring Program at Paducah Gaseous Diffusion Plant. ORNL/TM-13190. Environmental Sciences Division, Oak Ridge National Laboratory, Oak Ridge, Tenn.

Lewis, P.A. et al. 1994. Short-Term Methods for Estimating the Chronic Toxicity of Effluent and Receiving Water to Freshwater Organisms, EPA/600/4-91/002.

Stephan, C. E., D. I. Mount, D. J. Hansen, J. H. Gentile, G. A. Chapman and W. A. Brungs. 1985. Guidelines for deriving numerical national water quality criteria for the protection of aquatic organisms and their uses. U.S. EPA, Office of Research and Development. PB85-227049, NTIS, Springfield, VA.

EPA (U. S. Environmental Protection Agency). 1992. Interim guidance on interpretation and implementation of aquatic life criteria for metals. Office of Science and Technology, Washington, D.C.

EPA (U. S. Environmental Protection Agency). 1994a. Interim guidance on determination and use of water-effect ratios for metals, EPA-823-B-94-001. Office of Science and Technology, Washington, D.C.

EPA (U. S. Environmental Protection Agency). 1994b. Quality Control Supplement for Determination of Trace Metals at EPA Water Quality Criteria Levels Using EPA Metals Methods. Engineering and Analysis Division (4303), USEPA, Washington, D.C.

EPA (U. S. Environmental Protection Agency). 1995a. The Metals Translator: A Technical Guidance Manual.

EPA (U. S. Environmental Protection Agency). 1995b. Method 1669: Sampling Ambient Water for Trace Metals at EPA Water Quality Criteria Levels. EPA 821-R-95-034.

EPA (U. S. Environmental Protection Agency). 1995c. Federal Register Vol. 60, No. 86, May 4.

EPA (U. S. Environmental Protection Agency). 1996. Trace metals workshop. Chicago, IL. February 12-13, 1996. 


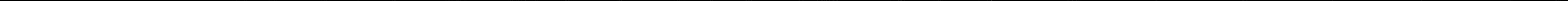


Appendix A

KENTUCKY DEPARTMENT OF ENVIRONMENTAL PROTECTION KENTUCKY DIVISION OF WATER

Procedures to Facilitate Alternative Metals Limits 

Procedures to Facilitate Alternative Metals Limits

Kentucky Department of Environmental Protection

Kentucky Division of Water

Frankfort, Kentucky

May, 1996

This report has been approved for release.
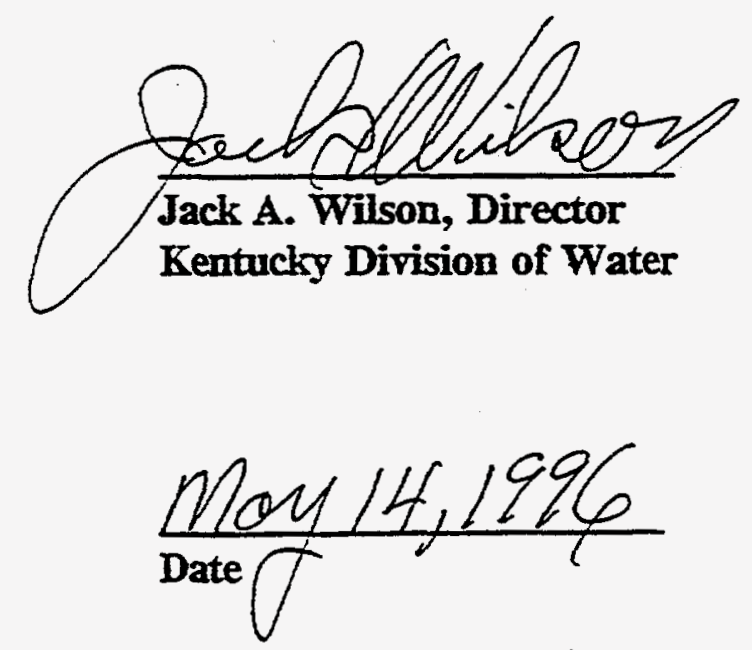


\section{Procedures to Facilitate Alternative Metals Limits \\ Kentucky Division of Water}

\section{Introduction}

Language in Kentucky's Warmwater Aquatic Habitat Criteria of the Surface Water Standards contained in 401 KAR 5:031 states that a demonstration may be performed to prove that a form of metal other than total recoverable (TR) is the cause of toxicity. This alternative to TR metal criteria was made in response to comments received during the 1992 triennial review of water quality standards and is consistent with recent EPA guidance (Office of Water Policy and Technical Guidance on Interpretation and Implementation of Aquatic Life Metals Criteria, USEPA 1993), which recognizes that TR metal criteria are often overly conservative.

The procedures outlined below, developed by the Kentucky Division of Water (Division), provide a straightforward manner in which permit applicants can demonstrate that alternative means of measuring compliance with TR metal limits are appropriate. Measuring dissolved metal in the wastewater (in cases where no instream dilution is available), or instream after mixing with receiving waters, and comparing it to dissolved metal permit limits would be a simple and generally conservative approach, but both Federal and State regulations require TR metal limits to be placed on permits. $401 \mathrm{KAR}$ 5:065 Section 3(3) states that TR must be used uniess another form of the metal is specified in the CWA or the analytical procedure measures another form of the metal (e.g. hexavalent chromium).

EPA issued Interim Guidance on Determination and Use of Water-Effect Ratios for Metals in February 1994 (EPA-823-B-94-001). The water effect ratio (WER) guidance suggested three levels of increasing complexity that could be used in interpreting aquatic life criteria: (1) TR metal (as Kentucky has historically done); (2) dissolved metal, using dissolved metal criteria; or (3) either of the above combined with a water-effects ratio that compares metal toxicity in stream water to that in lab make-up water.

The Division allows either the WER or its own procedures to be used in the alternative metal demonstration. Kentucky's procedures were originally drafted to address discharges into zero $7 Q 10$ flow streams that early WER methods did not adequately address. Although the latest WER methodology now accounts for these situations, Kentucky's methods offer the applicant a second alternative that may be easier to apply in certain instances.

Metals that are eligible for alternative limits are: arsenic, beryllium, cadmium, trivalent and hexavalent chromium, copper, iron, lead, nickel, silver, and zinc. Because of "free-from" narrative language in Section 2 of 5:031, it is also possible that a metal other than those with numerical criteria in Section 4 could be involved.

Mercury and selenium are not eligible for the alternative procedures. The divalent mercury cation, $\mathrm{Hg}(\mathrm{II})$, whether introduced directly or resulting from the oxidation of elemental mercury, 
can be transformed in the aquatic environment to methylmercury, which is both more toxic and more readily bioaccumulated. (The chronic criterion is based on levels in fish tissue and the resultant impact on human health, and the acute criterion is based on toxicity to aquatic organisms). Therefore, the mercury criteria should remain in TR form. The criteria for selenium were derived from field studies that related toxic effects to biomagnification of the metal, not toxic effects at the gill surface resulting from the availability of dissolved metal as is the case for most metals.

\section{Procedures}

The applicant must demonstrate through chemical-specific analyses and biomonitoring that an effiuent does not exhibit metal toxicity. A six-month testing period is necessary to account for effluent variability, without imposing undue testing or time constraints. Chemical analyses will be performed on the effluent on a monthly basis for the dissolved and TR forms of metals for which the applicant is seeking alternative limits. Because of recent controversy regarding quality assurance of dissolved metal results, care should be taken to reduce potential sample contamination both in the field and the laboratory by using "clean" techniques. These techniques are described by the U.S. Geological Survey and U.S. EPA" ${ }^{2}$.

Biomonitoring requirements (acute or chronic, availability of instream dilution) will be determined by the Division on a case-by-case basis according to the applicant's discharge and receiving stream characteristics. Definitive toxicity tests will be performed every month on the water flea Ceriodaphnia dubia and the fathead minnow Pimephales promelas,-as specified by Division biomonitoring protocol. Samples for biomonitoring and chemical analysis must be collected concurrently from the effluent.

Failure of two biomonitoring tests requires a toxicity identification evaluation (TIE) to determine if the metals in question were the cause of toxicity. Chemical data from these tests should be determined on samples used for the toxicity identification evaluation. If the TIE determines that metals are causing or contributing to toxicity, those metals are not eligible for alternative limits. The corresponding chemical data will assist in determining which metals are present in high enough concentrations to be contributing to the toxicity. Analytical results are used to determine the relationship between the TR and dissolved metal fractions. The ratio is initially developed with results from the six monthly samples, supplemented by earlier data if available. The ratio should be updated in subsequent years as the number of observations increases from continued dissolved and TR metal sampling.

Permit limits are based on the most stringent of the following: (1) the dissolved fraction cannot exceed Kentucky's aquatic life critera multiplied by EPA factors that convert TR criteria

${ }^{1}$ A Protocol for the Collection and Processing of Surface- Water Samples for Subsequent Determination of Trace Elements. Nutrients, and Major Ions in Filtered Water, Office of Water Quality Technical Memorandum 94.09

2Method 1669: Sampling Ambient Water for Trace Metals at EPA Water Ouality Critera Levels, EPA 821-R-95-034. 
to dissolved criteria (see Table 1);2) the total recoverable form of the metal cannot exceed human health criteria for fish consumption or domestic water supply, while accounting for any available dilution of the receiving water; or (3) the dissolved, total recoverable, or other specified form of the metal cannot exceed a technology-based limit as found in effluent guidelines. Also, for nondegradation purposes as described in $401 \mathrm{KAR} 5: 030$, a discharge into a High Quality Water will receive limits twice as stringent as in a Use Protected Water. The dissolved:TR ratio is used to determine sample compliance with total recoverable permit limits in (1) above in the following manner. The TR metal concentration of the effluent is first multiplied by the dissolved:TR ratio found from the six-month testing. This results in a "dissolved" concentration. As permit limits must be expressed as TR metal, the result must then be multiplied by the recipricol of EPA's criteria conversion factor (see Table 1). For example, assume that a chronic TR copper criterion is $0.010 \mathrm{mg} / \mathrm{l}$, and that sampling of $100 \%$ effluent (to a stream with a low flow of zero) has shown that the dissolved:TR ratio is 0.5 . Compliance sampling by the permittee shows TR leveis of $0.020 \mathrm{mg} / \mathrm{l}$ in the effluent. Applying the ratio of 0.5 results in a dissolved level of $0.010 \mathrm{mg} / 1$. The result then must be multiplied by the recipricol of EPA's criteria conversion factor (1/0.96 $=1.04$ ) to properiy compare it to the permit limit expressed as TR.

Metal concentration of effluent reported by permittee $=$ (TR metal of effluent $X$ Dissolved:TR metal ratio of effluent) $X$ VEPA criteria conversion factor

Continued biomonitoring will be required once the alternative metal procedures are in place to account for the potential for different ratios of dissolved to TR metal or higher levels of metal. Biomonitoring frequency will be as stipulated in the permit if the permit already contains toxicity monitoring, or at least semiannually if the permit does not aiready contain toxicity monitoring.

New facilities present different simations than existing dischargers. Upon receiving the application, the Division will inform the applicant of its options. However, a demonstration cannot be made until a permit has been issued and the facility built. Therefore, if a TR limit initially is given, the limit could be modified once the demonstration has been successfully completed.

As a result of the metals demonstration, facilities not normally subject to biomonitoring requirements may find that toxicity is present. The Division may then decide whether or not to place biomonitoring limits on the permit. 
Table 1. Criteria Conversion Factors for Dissolved Metals

\begin{tabular}{lll} 
Metal & Acute & Chronic \\
\cline { 2 - 3 } Arsenic & 1.000 & 1.000 \\
Cadmium $^{\text {b }}$ & 0.944 & 0.909 \\
Chromium III $^{\text {Chromium VI }}$ & 0.316 & 0.860 \\
Copper & 0.982 & 0.962 \\
Lead & 0.960 & 0.960 \\
Nickel & 0.791 & 0.791 \\
Silver & 0.998 & 0.997 \\
Zinc & -0.85 & NA \\
Linc & 0.978 & 0.986 \\
\hline
\end{tabular}

2Source: USEPA, Federal Register Vol. 60, No. 86, May 4, 1995, p. 22231, Table 2

${ }^{b}$ Conversion factors are hardness-dependent. The values shown are with a hardness of 100 $\mathrm{mg} / \mathrm{l}$ as $\mathrm{CaCO}$. Conversion factors (CF) for any hardness can be calculated using the following equations:

Cadmium

Acute: $\mathrm{CF}=1.136672-[(\ln$ hardness $)(0.041838)]$

Chronic: CF $=1.101672-[(\mathrm{ln}$ hardness $)(0.041838)]$

Lead

Acute and Chronic: CF $=1.46203-[($ In hardness $)(0.145712)]$ 

Appendix B

AGREED ORDER OF DISMISSAL

(File No. DOW-20277-056) 


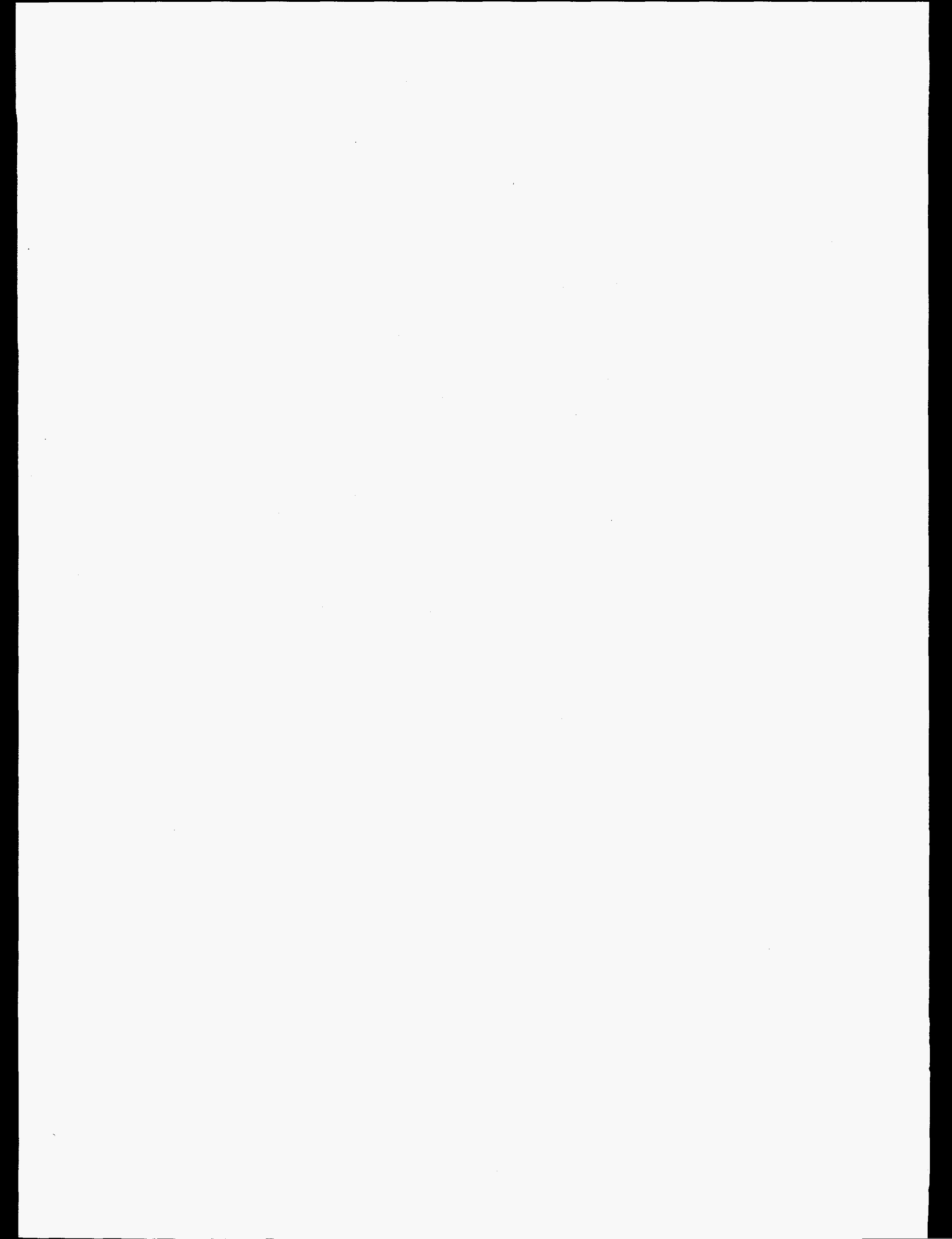




\section{COMMONWEAITH OF XENTUCKY \\ NATURAI RESOURCES AND \\ ENVIRONMENTAI PROTRCTION CABLNET \\ FILE NO. DOW-20277-056}

UNTIED STATES DEPARTMENT OF ENERGY, PADUCAF GASEOUS DIFFUSION PLANT PEITIIONER

vS. AGREED ORDER OE DISMTSSAL

NATURAI RESOLRCES AND

ENVIRONMENTAL PROTECTION CABINET

RESPONDENT

WHEREAS, the parties to this Agreed Orcier, the Natural Resources and Enviromontal Protection Cabinet (hereinafter "Cabinet") and United States Deparment of Energy, PBducah Gaseous Diffursion Plant (hereinafter "DOE") and the United States Enrichment Corporation (hereinater "ISEC"), state:

1. The Pedueat Gaseous Diffusion Plant (PGDP), loeated approximately ten (10) miles west of Paducah, Kenoucky, is a uranium esriciment facility owned by the United States Deparwoeat of Energy (DOE).

2. DOE and USEC discharge wastewater to the Big Bayou and Littie Bayou Creaks. The facility was operated fom October 12, 1987, through October 31, 1992, purstant to an Agreed Order issued Octeber 12, 1987, relating to the chailenge of a Kenrucky Pollutant Discharge Elimination Systen (KPDES) Persit Nursber KYO004049 issued to the DOE October 22, 1986 by the Kentuciry Division of Water (KDOW). 
3. Pursuant to Tive [X of the Energy Policy Act of 1992, the USEC was established as a wholly ouned government corporarion. In accordence with the Energy Policy ACt, the USEC and DOE entered isto an agreement pursuant to which USEC is loasing portions of PGDP effective as of July 1,1993 . At the Don-leased premises of PGDP, DOE continues to perform various activities including deconeamination, decommissiosing, and environmental response actions and correetive actions. DOE conducts its activixies at PGDP primarily ihrougin Lockheed Marin Evergy Systems, lnc., a wholly ownec subsidiary of Lockheed Martin Technologies, lnc. USEC conauets its aczivities at PGDP trough an operatisg contractor, Lockineed Martin Utility Services, Loc., aiso a wholly owned subsidiary of Loekcheed Marin Technoiogies. Iae.

4. Since 1987, DOE has performed a comprehensive biological monitoring program assessing the biological impacts to Big Bayou and Little Bayou Creeks.

5. On May 9, 1991, DOE made an application for a KPDES pemit.

6. On September 29, 1992, the Cainines reissued KPDES Permit Number KY0004049 to DOE as a finai action. The pemit, by its terms, became effective on November 1, 1992, and requires compliance with the new and more stringent effuent limitations on and after that date. In Soptember 1993. USEC was added to the permit to discharge under the KPDES system, thereby authorizing USEC to discharge from PGDP to cerain receiving warers. The effective date of this addition to KPDES Pernit No. KY0004049 was Novessber 1, 1992.

7. On Ocrober 21, 1992, DOE peritionod the Cabinet for a hearing requesting relief from certain limits in KPDES Permit No. KY0004049. These limits are copper, cadmium, chromium, leach nickel. zire. temperanure, phosphorous, pHi and cinronic toxicity. 
8. On Octoice 21, 1992, DOE requested that the Cabinet issue a stay of these specified limits contained in KPDES Permit No. KY0004049.

9. On October 28, 1992, the Cabinets Offee of Administrative Fiearings issued an Order grapting a stay of certain permit conditions.

10. PGDP submitted a Plen for Development of Altemative Temperamre Iimit to the KDOW under cover letter dated August 8. 1994.

Now, therefore, in the interest of setting the isgues involved in this challenge to the KPDES permit, the parties agree as follows:

11. DOE and ISSEC shail meet the KPDES permir limit for phosphorus upon entry of this final Agreed Order.

12. The KPDES permit limits for all other parameters except lead ciromium, cadmiver copper, nickel, zinc (hereinater metals), texperaurs and $\mathrm{pH}$, shall be flnai and remaio in effect upon any of this final Agreed Ordex. The KPDES permit linirs for lead, admium, chromium, copper, aickel, zane, tempesastre and piH sinall be govemed by itris Agreed Order until the Cabiset makes its Enal determinations on these paramexers under this order. At that time, DOE and USEC shall have weaty (20) days to request a say of the final limits or comply with the determination.

13. TEMAERATIRE: DOE anc L'SEC shall conduet the tempenanse sady us described in paragraph 10 and approved by KDOW Seprember 27, 1994 for ourfalls 001,008 , and the effluent from C-617 lagoon whether it be discharged from ourall 010 or 011 for the purpose of determining the variabillty in temperaure of the effuent discharges in Big Bryou Creek and Little Bayou Creek. The interien temperanire limir sinall be $95^{\circ}$ Fainreniseit at a monthiy average, $100^{\circ}$ Fahreaheit daily maximum until the intertm linit is terminated in accordance with this Agreed Order. DOE and 
USEC sinil submit the results of the study to the Kenucky Division of Water on or before April \&, 1996. The parties agree that any data coilected as part of this suriy will sot bo inciuded in the Discharge Monitoring Repors. At the end of the saddy and after review of the study results the Cabinet saell notify DOE and USEC of its final determination regarding altersadve temperature Linits. DOE and USEC shall retain the right to petition for beading pursuant to KRS 224.10-420(2) or may make appiication for a new permit decision depending upon the Cabinets determination. Compliance with this paragraph shall consriture compliance with the temperantre requiremenss of the permit All other ouffalls shall meat the XPDES Persit limit for temperature upon eaty of this Agreed Orcer. If the Cabinet cetemines that the temperaure limies should be less than the interim Iimits containec in this Agreed Order then DOE and USEC, within thirty (30) days of receiving the Cabinet's notice, shall submit to the Cabinet 2 pian and schedule for coming into complianee with such new tempesanse linits. Upon approval by the Cabinet, DOE and USEC shall comply with the approved plan and schedulo to come into compliance with such new semperanure linits.

14. 2H: DOE and USEC shall stibmit a proposal to concuct instream monitoring for $\mathrm{pH}$ ir Big Bayou Creex and Litle Bayou Creek to evaluate the impact of effluents with pHi greater than 9.0 on ambient water quality. The study will focus on impaces of effluents from outfalis 001,006 , C08. 009, and the effluent from the C-617 lagoon whether it be discharged from ourfall 010 or 011 . A drafi proposal shall be submined as soor as possibie but in no case iarer than three (3) months following the entry of this Agreed Orcier. Monitoring of instrearn pli will comnence tbirty (30) days after the Cabinet grants approval of the moniroting plan. After the completion of twelve (12) xonihs of monituring, a comprehensive roview of the monitoriog date shail be conducted by DOE and USEC and tie Kennucky Division of Water to detemine the impact of the discharges from the 
oufail(s) in questions. Based on the Indings of this review, DOE and LSEC shall, within one (1) year, install pif control systerns at any ourfall whose effluent causes Big Bayou Creek or Little Bayou Creek to exceed the warm water quality standard of 9.0 pit. For the outalls surdied for any outfall whose effluent does not cause Big Bayou Creek or Litrlo Bayou Creek to exceed the warm water quality standird of $9.0 \mathrm{pH}$, final effluent limits shall be based upon that pH discharge limit which is foumd not to cause environmenial harm, not to exceed a moxirnun of $10.5 \mathrm{pH}$. DOE and USEC shail retain the right to perition for hesring pursurant to KRS 224.10-420(2) to contest the question of whether or sot the Cabinets ñnal determination as to pH was propes. An interim limit of 6.0 io $10.5 \mathrm{pH}$ shall epply to oufalls 001,006,008,009, and the effluent ind the C-617 lagoon, whether it be disoherged from outfall 010 or 011 , until these interim limits are terrainated by this Agreed Order. All otber outalls not subject on the pHI studies sball meet the KPDES permit limit for pH upos entry of this Agreed Orde:. DOE and USEC reserve the right to petition the Cabinet for an exception 20 enteria as provided for in 401 KAR 5:031, Section 9. Compliance with this paragraph shall constisute compliance with the pir requirements of the permit. Data collected in Steam will be repored but will not be included on Discinarge Monitoring Reports.

15. METALS: 401 KAR 5:031 sets the water quality crizeria for cersin motais. Pursuant to 401 KAR 5:031, metals criteria afplied to ine KPDES permit are "total recoverable metals" to be measured in an unfiltered sample unless it can be cesonstrated to the satisfaction of the Cabinet that a more appropriate analytical techniọue or criteria is available which provides a better measurement of that portion of the metals present which causes toxicity to aquatic life. DOE and USEC shail conduct studies to develop alternative mecal limirs prrsuant to the above regulations for DOE and USEC ouralls 001, 002, 003, 008,009, 010,011,012, 013,015, 016, 017, and 018 (except during 
heavy rainfall events ourfalls 002, 010,011, and 012 siall be compositod in the C-617 lagoon, decbloriantod and disobarged from outfall 010 or nutfall 011). All other outfalls shall meet the KPDES permit limit for metals upon eatry of this Agreed Order. A draft plan shall be submitted to the Cabinet for review as soon as possible but no laler than three (3) months following the entry of this Agreed Order, with a final repart suborized to the Cabinet in accordance with the sehedule outlined in the approved plan DOE and USEC may atrempt to develop altemative metal limits for cadmiuso, chrominem, copper, lead, nickel, and zinc. If pursuant to 401 KAR 5:031, DOE and USEC prove to the sarisfaction of the Cabinet that a more appropriate analydcal tectanique or erteria is available which provides a better measurement of that portion of the metals present winich causes toxicity to aquatic life, the Cabinet will propose to modify the peemit to inoorporate these aiteressive

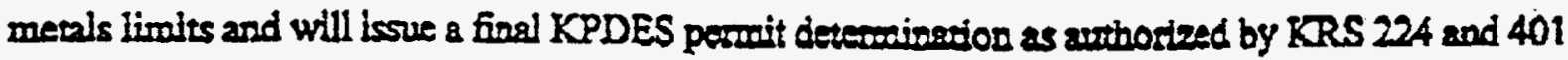
KAR Cbapter 5. Until the process is complete, DOE and USEC shall monitor for cadmium, chrominea, aiokel, lead, copper and zino ead repor the reselis. Tho data collected as a part of this strdy and reported pursuant to the previous section shall not be inciuded in the discharge monitoring separs. In lieu of metsis linits, DOE and USEC shali comply with the requirements specified io Part III, Sections E and E of KPDES Permit No. KYO004049 issued September 29, 1992. This section establishes a whole effuent toxicity limit of $1 \mathrm{TJ}$, for outralls $001.006,008,009$, and the effluent fom the $\mathrm{C}-617$ lagoos (composited $002,010,011,012$ ) dischwrged from ontfall 010 or 011 and requires testing of these ouffalls to be conducted quarteriy. Outfills $013,015,016,017$, and 018 will also be rested quarterly for toxicity and the resuits reported on the Discharge Monitoring Repors. DOE and USEC retain all rights to perition for hearing pursuant to KRS $224.10420(2)$ to contest the question of whether or not the final determination of the Cabinet regardiag alvernative 
metals limits was proper. Complianco with this paragrapid shall constirute compliance with the cadmium, chromiura, aickel, lead, copper and zinc requiraments of tho permit. DOE and USEC reserve the right to petioion the Cabinet for an Excoption to Criteris as provided for in 401 KAR 5:031, Section 9.

$\therefore$ 16. Those conditions of the permit not specifeally addressed in this Agreed Order are final and shall remain in effect. Monitoring frequencies for all parameters shall be as required in KPDES Permit No. KY0004049 unjess otherwise specified in this Agrod Order. Any previous Afread Orders berween the parties involving DOE and USEC's KPDES parmit ane expressly reminated. The interim limits for temperanure and pH provided in this Agreed Order shall terminate no later than (a) if no epplicarion for persnit is tinely fled, the eqiation dxe of the permit Oetober 31,1997 or (b) if an application for a peroedt is tircely filed, the date a subsequent RPDES permit is issued.

17. The DOE and USEC apree that this Apred Order only resolves the permit challeage to KPDES Permit No. KYOO04049 Eled in action amber DOW 20277-56. The DOE and USEC agree there are other marters with the Cabinel not reinted to this Agreed Order, that this Agreod Order does not address. To the exteat any interim liraits are deemed by DOW to satisty warer qualiry standards, these limits will be considered when the permit is reiseued.

18. DOE shail use its best effarts and, take all necessary steps to obtain timely funding to meet the obligations under this Agreed Order. It is DOE's position that any requirement for the payment or obligation of funds to perform required sadies under this Agreed Order is subject to the availability of appropriated finds and that no provigion of this Agreed Onder should be interpreted to require obligation for payment of fuads in viointion of the Anti-Deficiexcy Act, 31 U.S.C. Seotion 
1341, as unended. It is the Cabinet's position that the Act or any other defense besed on the lack of appropriations or finding does not appiy to the activities and requirements of this Agreed Order and that DOE's obligations under this Agreed Orcer gre not affected by its failure to obtain adequate funds or appropriations from Congress. The parties reservo thair respective sights, positions, and defenses on the issue. Pailure to obtain adequate funds or appropriations from Congress does not in any way release DOE from its ultimate obiigation to comply with the effoctive terms and conditions of KPDES Permit No. KYO004049. Subject to the tarms of this Agroed Order, if DOE maintains adequare funds are not availablo to fulfill its obligations under this Agreed Order, the partios agree to meet to determine if now distes reguiring the payment or obligations of such furds can be agreed upon. If the paries ure unable to resolve their differences on these issues, the Cabines reserves the right to initiate any other remedy that it would have absent this Agreed Order.

19. This Agreed Order is a final order in action DOW 20277-56 and this action is bereby dismissed.

20. The Cabines does not, by its consent to the eatry of bihis Agueed Order, warrant in any manner that DOE and USEC's complete complinnee with this Agreed Order will result in compliance with the provisions of all statutes under the Cabinets jurisdiction and any regulations adopted pursuant thereto. Notwithstanding the Cabinet's seview and approval of any piens formuiated. pursuans wo this Agreed Order, DOE and USEC shail remain sololy responsible for compliance with the terms of any stante under the Cabinet's jurisdiction and the regulations adopted pursennt thereto, this Agreed Order and any Other permit requirements.

21. The Cabinet enters this Agreed Order based on informstion providad by the DOR and USEC. Nothing contsined berein siall be construed to waive or to limit sny remedy or cause of 
action by the Cabinet based on stanutes or regulatioas under its jurisdiction and DOE and USEC reserves their defenses thereto. The Cabinet expressly reserves its right at any time to issue administartive orders and to take any other action it deems necossary, including the rivit to order all zecessary remediai measures, assess panaties for violations, or recover all ropponso costs incirrod, and DOE and USEC reserves their defenses thereto. This Afreod Order shall not preveat the Cabinet from issuing, zoissuing, renowing, modifying, revoking, suspending, denying, terminating, or reopening any permit to DOB and USEC. DOE and USEC reserves their defenses thereto, exeept thas DOE and USEC shall nos use this Agreed Order as a dofense.

22. This Agreed Order may got be amended except by a written onder of the Cabinet's Secretary. DOE and USEC may request an smeadment by writiog the Cabinet and staring the reasons for the requer. If granted, the amended Afreed Order sball not affeot any provision of this Agroed Order uniess expressly provided in tho amended Afreed Onder. Upon receipt of a written request, the Cabiner say, in its sole discretion, accord DOE and USEC an extension of time rasanably neded far DOE and USEC to complete their performanee under the orms of this A freed Orcies. Such extension must be by Agreed Order and the request shall be tondered prior to the time periomance is due. Such a reguest shall be submitted directly to the Director of the Division of Warer, 14 Roilly Rosed Franlfiort Kenaucly 4060i. DOE and USEC retain all rights to pectition for bearing to consest the Cabinet's decision on any request for an anendineat to this Afreed Order. Except as provided for in paragraph 18 of this Agreed Onder, economic factors sball sol be considered as grounds for an extension.

23. The parties resognize that any major modification to this permit will require the Cabirtet to ubide by the public notification and public heariag requirements of 401 KAR Chapter 5. 
24. The provisions of this Agreed Order shall appiy to and be binding upon the parties to this action, their offecers, directors, agents, successors, assigms, and all persons, firms and corporations in active concert or participation with them. DOE and USEC shail give notice of this Agread Onder to any successons in interest prior to the transfer of ownership and/or opernition of any part of thair now existing facllity and shall notify the Narural Resources and Environmemeal Protection Cabinet that such notice has been given and follow' all stantory and regutatory requirements for much a transfer.

25. This Agreed Orier shall be of no force and effect unless and unil it is entered by the Secretary or his designee as evidenced by his signagare thereon.

AGREED TO BY:

Authorized Representative for the United States Dapartaneat of Energy, Paducah Gaseous Diffirsion Plant
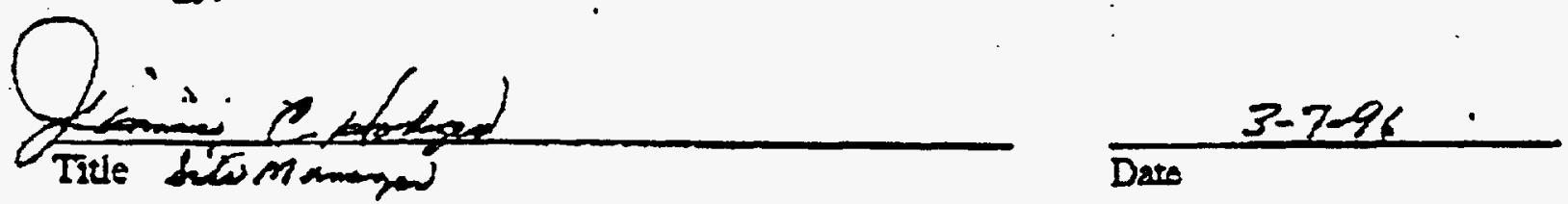

Authorized Representative for the Unired Stares

Enrichment Carporation

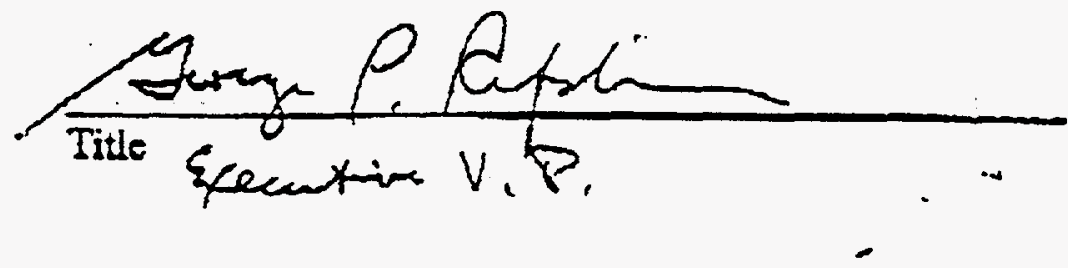

\section{6}

Date 
U1:11 4

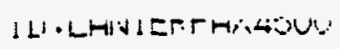

Frort i irto

$361-654-3210$

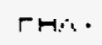

rhac

$1996 \cdot 05-07$

$15: 18$

N011 P.12/14

49

FILENO. DOW-20277-056

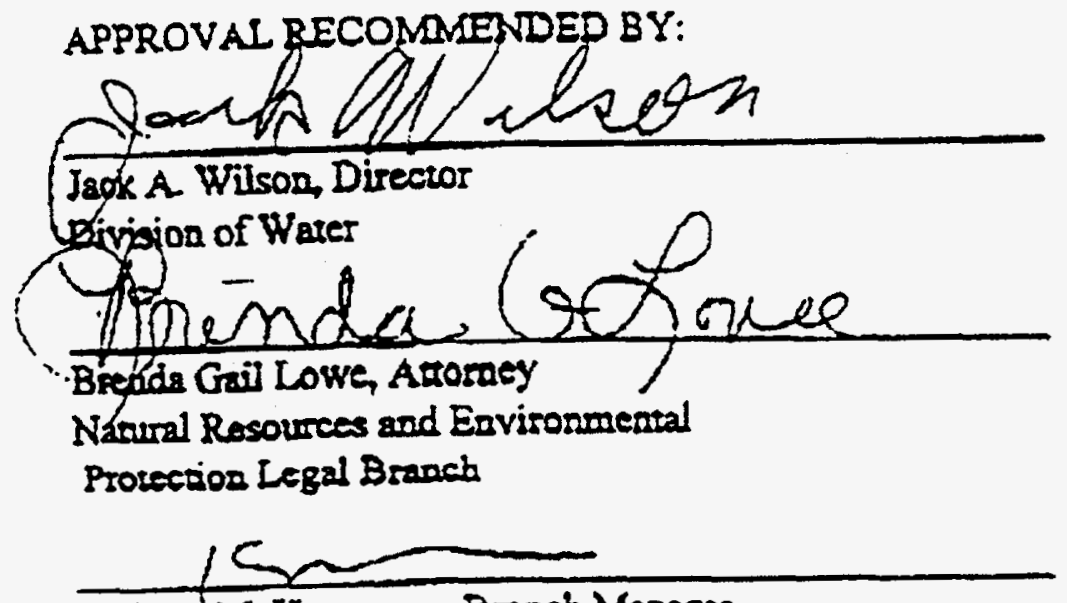

Kathrya M. Fiargraves, Branah Manages Nawsol Resourees and Environmental Protection Cribinet

Alenra a Cuny

Glenns Jo Curry loteneral Coudsel Office of Legal Services

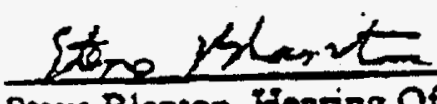

Sreve Blencon, Fearing Officer Office of Administrative Hearings
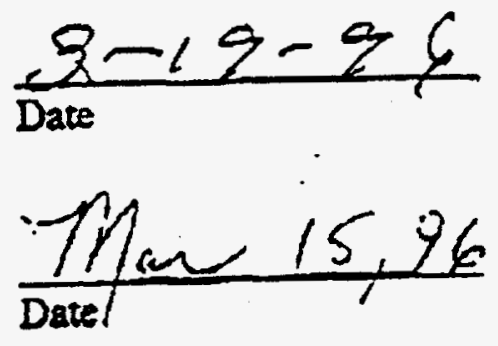

$\frac{3 \cdot 31 \cdot 56}{D a t e}$

Date

$$
\frac{3-3-96}{\text { Date }}
$$

$$
\frac{4 / 3 / 56}{\text { Date }}
$$

ORDER

WIIEREPORE, the forgoing Agreed Order is entered as the final Order of the Nanum Resources and Environmestal Protection Cabinet this 5th day of Cacel 1996.

NÁTURAL RESQURCES AND

ENVTRONMIENTAL PROTECTION CABINET

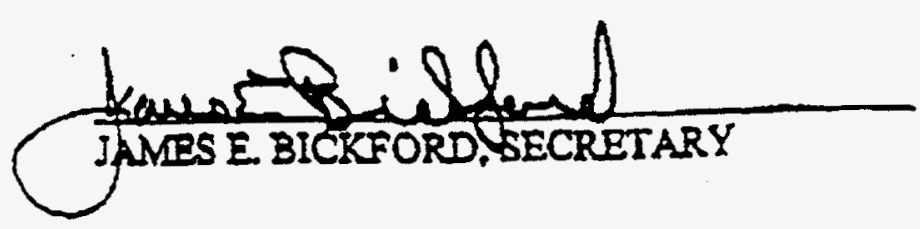




\section{CERTIFICATE OF SERYICE}

I hereby certify that a true and accurate copy of the foregolng AGREED ORDER OF

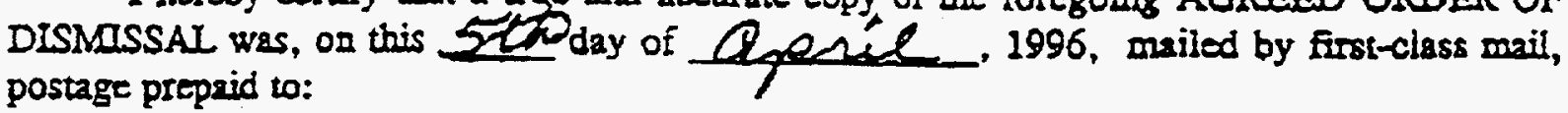
HON. TERRI SLACK

HON. RACFEI BLUMENFEID

U.S. DEPARTMENT OF ENERGY

P.O. BOX 2001

OAK RIDGE, TN $37831-8510$

HON. DENNIS SCOTI

T. MIIKE TAIUI

ASSISTANT GENERAL COUNSEL

UNIIED STAIES ENRICIIIENTT CORPORATION

6903 ROCKIEDGE DRTVE

BETHESDA. MD 20817

HON. DANE A. BARTLETT

LOCKEEDD-MARIIN UTILTTY SERVICES

P. O. BOX 1410

PADUCAI, KY 42001

- UNIIED STATES DEFT OF ENERGY

PADUCAI SITE OFFICE

P. O. BOX 1410

PADUCAH, KY 42001 
and hand dellvered:

Hon. Brands Lowo

Hoa. Michael Williamson

Office of Legal Services

Natural Resources end

Enviromental Protection Cabinet

Fifth Floor, Cepital Pleze Tower

Franicfort, Keosucicy 4060 I

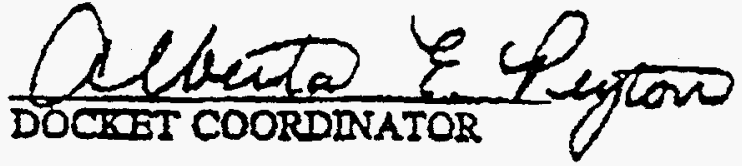

Distribution:

Division of WateriJack Wilson

\section{LTS}

Fierring Officer, SB

Order Pile

$\sqrt{\mathrm{K}}$

KDB 

ORNL/TM-13258

\section{INTERNAL DISTRIBUTION}

$\begin{aligned} \text { 1. } & \text { L. D. Bates } \\ 2 . & \text { B. A. Berven } \\ 3 . & \text { R. B. Cook } \\ 4 . & \text { V. H. Dale } \\ \text { 5. } & \text { D. E. Fowler } \\ 6 . & \text { S. G. Hildebrand } \\ 7 . & \text { B. K. Konetsky } \\ \text { 8-22. } & \text { L. A. Kszos } \\ 23 . & \text { J. M. Loar } \\ 24 . & \text { G. W. Morris } \\ 25 . & \text { M. J. Peterson } \\ \text { 26-30. } & \text { T. L. Phipps }\end{aligned}$

1. L. D. Bates

2. B. A. Berven

3. R. B. Cook

4. V. H. Dale

5. D. E. Fowler

6. S. G. Hildebrand

-22. L. A. Kszos

23. J. M. Loar

24. G. W. Morris

26-30. T. L. Phipps
31. M. G. Ryon
32. D. S. Shriner
33. J. G. Smith
34. G. R. Southworth
35. S. H. Stow
36. Central Research Library
37. ESD Library
38-39. Laboratory Records Dept.
40. Laboratory Records, ORNL-RC
41. ORNL Patent Section
42. ORNL Y-12 Technical Library

\section{EXTERNAL DISTRIBUTION}

43. D. L. Ashburn, Lockheed Martin, 761 Veterans Avenue, Kevil, KY 42053

44. M. Broido, Acting Director, Environmental Sciences Division, Department of Energy, 19901 Germantown Road, Germantown, MD 20874

45. F. A. Donath, Director, Institute for Environmental Education, Geological Society of America, 1006 Las Posas, San Clemente, CA 92673

46. D. W. Freckman, Director, College of Natural Resources, 101 Natural Resources Building, Colorado State University, Fort Collins, CO 80523

47. D. R. Guminski, Lockheed Martin, 761 Veterans Avenue, Kevil, KY 42053

48. J. D. Hankins, Lockheed Martin Utility Service, P.O. Box 1410, Paducah, KY 42002

49. D. F. Hutcheson, Jr., Lockheed Martin Energy Systems, P. O. Box 1410, Paducah, KY 42002

50-54. V. W. Jones, Lockheed Martin Energy Systems, 761 Veterans Avenue, Kevil, KY 42053

55. Kevil Document Center, Lockheed Martin Energy Systems, 761 Veterans Avenue, Kevil, KY 42053

56. A. Patrinos, Associate Director, Environmental Sciences Division, Office of Health and Environmental Research, G-165, U.S. Department of Energy, Germantown, MD 20874

57. G. S. Sayler, Professor, 10515 Research Drive, Suite 100, The University of Tennessee, Knoxville, TN 37923-2567

58. W. D. Tidwell, DOE Site Office, P.O. Box 1410, Paducah, KY 42001

59-62 C. C. Travis, Lockheed Martin Utility Service, P.O. Box 1410, Paducah, KY 42002

63. Office of Assistant Manager for Energy Research and Development, U.S. Department of Energy Oak Ridge Operations, P.O. Box 2001, Oak Ridge, TN $37831-8600$

64-65. Office of Scientific and Technical Information, P.O. Box 62, Oak Ridge, TN 37831 